\title{
Creation of Apolipoprotein C-II (ApoC-II) Mutant Mice and Correction of Their Hypertriglyceridemia with an ApoC-II Mimetic Peptide ${ }^{\mathbb{S}}$
}

\author{
Toshihiro Sakurai, Akiko Sakurai, Boris L. Vaisman, Marcelo J. Amar, Chengyu Liu, \\ Scott M. Gordon, Steven K. Drake, Milton Pryor, Maureen L. Sampson, Ling Yang, \\ Lita A. Freeman, and Alan T. Remaley \\ Lipoprotein Metabolism Section, Cardio-Pulmonary Branch, National Heart, Lung, and Blood Institute (T.S., A.S., B.L.V., M.J.A., \\ C.L., S.M.G., M.P., L.A.F., A.T.R.), Transgenic Core Facility, National Heart, Lung, and Blood Institute (C.L.), Department of \\ Laboratory Medicine, Clinical Center (M.L.S., A.T.R.), Critical Care Medicine Department, Clinical Center (S.K.D.), and Laboratory \\ of Obesity and Metabolic Diseases, National Heart, Lung, and Blood Institute (L.Y.), National Institutes of Health, Bethesda, \\ Maryland
}

Received September 29, 2015; accepted November 11, 2015

\section{ABSTRACT}

Apolipoprotein C-II (apoC-II) is a cofactor for lipoprotein lipase, a plasma enzyme that hydrolyzes triglycerides (TGs). ApoC-Il deficiency in humans results in hypertriglyceridemia. We used zinc finger nucleases to create Apoc2 mutant mice to investigate the use of C-II-a, a short apoC-II mimetic peptide, as a therapy for apoC-II deficiency. Mutant mice produced a form of apoC-II with an uncleaved signal peptide that preferentially binds high-density lipoproteins (HDLs) due to a 3amino acid deletion at the signal peptide cleavage site. Homozygous Apoc2 mutant mice had increased plasma TG $(757.5 \pm 281.2 \mathrm{mg} / \mathrm{dl})$ and low HDL cholesterol $(31.4 \pm 14.7$ $\mathrm{mg} / \mathrm{dl}$ ) compared with wild-type mice (TG, $55.9 \pm 13.3 \mathrm{mg} / \mathrm{dl}$; HDL cholesterol, $55.9 \pm 14.3 \mathrm{mg} / \mathrm{dl}$ ). TGs were found in light (density $<1.063 \mathrm{~g} / \mathrm{ml}$ ) lipoproteins in the size range of very-

\section{Introduction}

Elevated plasma triglycerides (TGs) are now recognized as an important and independent risk factor for atherosclerosis (Nordestgaard et al., 2007). In addition, patients with severe hypertriglyceridemia can also develop pancreatitis (Athyros et al., 2002), particularly when TG levels exceed 1000-1500 $\mathrm{mg} / \mathrm{dl}$ (Tsuang et al., 2009). As many as 40 different genes are now known to regulate plasma TG (Johansen et al., 2011), but only a few monogenetic disorders are known to markedly increase TG (Nordestgaard and Varbo, 2014). Rare genetic defects in lipoprotein lipase (LPL) (Benlian et al., 1996), the main enzyme responsible for the hydrolysis of TG on lipoproteins,

This research was supported by intramural National Institutes of Health funds from the National Heart, Lung, and Blood Institute.

dx.doi.org/10.1124/jpet.115.229740.

S This article has supplemental material available at jpet.aspetjournals.org. low-density lipoprotein and chylomicron remnants (40-200 $\mathrm{nm})$. Intravenous injection of C-II-a $(0.2,1$, and $5 \mu \mathrm{mol} / \mathrm{kg})$ reduced plasma TG in a dose-dependent manner, with a maximum decrease of $90 \%$ occurring 30 minutes after the high dose. Plasma TG did not return to baseline until 48 hours later. Similar results were found with subcutaneous or intramuscular injections. Plasma half-life of C-II-a is $1.33 \pm 0.72$ hours, indicating that C-II-a only acutely activates lipolysis, and the sustained TG reduction is due to the relatively slow rate of new TG-rich lipoprotein synthesis. In summary, we describe a novel mouse model of apoC-II deficiency and show that an apoC-II mimetic peptide can reverse the hypertriglyceridemia in these mice, and thus could be a potential new therapy for apoC-II deficiency.

ABBREVIATIONS: apoC-II, apolipoprotein C-II; FFA, free fatty acid; FPLC, fast protein liquid chromatography; HDL, high-density lipoprotein; HDL-C, HDL cholesterol; IDL, intermediate-density lipoprotein; KO, knockout; LC-MS/MS, liquid chromatography-tandem mass spectrometry; LDL, low-density lipoprotein; LPL, lipoprotein lipase; LRA, lipid removal agent; PBS, phosphate-buffered saline; PCR, polymerase chain reaction; PL, phospholipid; TC, total cholesterol; TFA, trifluoroacetic acid; TG, triglyceride; VLDL, very-low-density lipoprotein; WT, wild type; ZFN, zinc finger nuclease. 
We recently described a novel bihelical apoC-II mimetic peptide called C-II-a (Amar et al., 2015). The first helix is based on the 18A peptide (Chung et al., 1985), which readily binds to lipoproteins and has been previously used in the design of other apolipoprotein mimetic peptides (Anantharamaiah et al., 1985; Bloedon et al., 2008; Amar et al., 2010). The second helix contains part of the LPL activation domain of the third helix of apoC-II. This peptide was found to be equimolar in its potency compared with the full-length apoCII protein in activating LPL for both artificial triglyceride-rich emulsions and native lipoproteins (Amar et al., 2015). When added to human serum from patients defective in apoC-II, CII-a restored lipolysis to levels observed after adding the fulllength apoC-II protein. Furthermore, it activated lipolysis in vivo when given to apoc2-knockout (KO) zebrafish (Liu et al., 2015). Unexpectedly, the C-II-a peptide also stimulated lipolysis when added to serum from patients with type IV and type V hypertriglyceridemia (Amar et al., 2015), indicating that the availability of apoC-II may be rate limiting for some types of dyslipidemia. Treatment of apoE-KO mice with the C-II-a peptide also lowered serum triglycerides (Amar et al., 2015). C-II-a is also able to accept cholesterol effluxed from macrophages in vitro, which may be beneficial for overcoming atherosclerosis (Amar et al., 2015). Overall, these results suggest that the C-II-a peptide, which is easily synthesized and less expensive than full-length apoC-II protein, could possibly be used as a novel treatment of apoC-II deficiency, as well as a treatment of other forms of hypertriglyceridemia for reducing the risk of pancreatitis and cardiovascular disease.

Several different genetic mouse models of hypertriglyceridemia have been previously described (Shachter et al., 1994; Weinstock et al., 1995; Beigneux et al., 2007; Garelnabi et al., 2013), but no mouse models of apoC-II deficiency have been reported. To test the feasibility of using the C-II-a peptide for the treatment of apoC-II deficiency, we describe, for the first time, the generation of apoC-II mutant mice using zinc finger nucleases (ZFNs) (Carbery et al., 2010; Cui et al., 2011). We first characterize the hypertriglyceridemic phenotype of these mice and then demonstrate that relatively low doses of the CII-a peptide, when delivered intravenously, intramuscularly, or subcutaneously, rapidly lower triglycerides for several days. These results indicate that C-II-a could possibly be used as a novel therapy for apoC-II deficiency.

\section{Materials and Methods}

Zinc Finger Nuclease mRNA Preparation and Microinjections of Mice. ZFN constructs targeting the third exon of the mouse Apoc2 gene were designed and synthesized by Sigma-Aldrich (St. Louis, MO) using their CompoZr Zinc Finger Nuclease Technology. The sequences of targeted regions were 5'-TCCCTCAGAGGTCCAG-3' for ZFN1 and 5'-CAGGAAGATGACTCGGGC-3' for ZFN2. Apoc2 mutant mice were created in the Transgenic Core facility of the National Heart, Lung, and Blood Institute. Fertilized oocytes were collected from normal FVB/6NJ (stock 001800; The Jackson Laboratories, Bar Harbor, ME) or B6CBAF1 (stock 100011; The Jackson Laboratories) females, and microinjected into the pronucleus and/or cytoplasm with pooled RNAs for both ZFNs $(20-40 \mathrm{ng} / \mu \mathrm{l})$ dissolved in $10 \mathrm{mM}$ Tris ( $\mathrm{pH} 7.4$ ) with $0.1 \mathrm{mM}$ EDTA. After culturing overnight in a $37^{\circ} \mathrm{C}$ incubator, surviving two-cell embryos were implanted into the oviducts of pseudopregnant Swiss Webster females (Taconic, Hudson, NY) (Liu et al., 2013). Founder mice were crossed onto the C57BL/6 background for three generations, and wild-type siblings of the same generation were used as controls. All animal experiments were approved by the National Heart, Lung, and Blood Institute Animal Care and Use Committee (protocol \#H-0050).

For genotyping, DNA isolated from tail clips or blood with the Maxwell 16 System (Promega Corporation, Madison, WI) was sequenced for the initial characterization of Apoc2 gene mutations in founder mice. First, the region spanning exon 3 of the mouse Apoc2 gene was polymerase chain reaction (PCR) amplified. Each $30-\mu$ l PCR reaction contained $3.0 \mu \mathrm{l}$ of $10 \times$ PCR buffer (Invitrogen, Carlsbad, CA), $0.9 \mu \mathrm{l}$ of $\mathrm{MgCl}_{2}(50 \mathrm{mM}), 0.6 \mu \mathrm{l}$ of $\operatorname{dNTP}(10 \mathrm{mM}), 0.24 \mu \mathrm{l}$ of each primer $(25 \mu \mathrm{M}), 0.2 \mu \mathrm{l}$ of Taq DNA polymerase (5 U/ $\mu \mathrm{l}), 19.82 \mu \mathrm{l}$ of pure water, and $5 \mu \mathrm{l}$ of template DNA (about $20 \mathrm{ng} / \mu \mathrm{l}$ ). The following program was used: $94^{\circ} \mathrm{C}, 3$ minutes; 35 cycles of $94^{\circ} \mathrm{C}$ for 30 seconds, $55^{\circ} \mathrm{C}$ for 35 seconds, and $72^{\circ} \mathrm{C}$ for 30 seconds; and a final extension at $72^{\circ} \mathrm{C}$ for 4 minutes. The following primers were used: forward primer, 5'-TCCTGATGTTGGGAAATGGT-3'; reverse primer, 5' -TTTCTCAT CCATGCTGATCG-3'. The size of the amplicon was $331 \mathrm{bp}$. Each PCR reaction was cloned using a TOPO TA cloning kit for sequencing (catalog no. K4575-01SC; Thermo Fisher Scientific, Carlsbad, CA). Amplified plasmids were purified using a miniprep kit (Zymo Research, Irvine, CA). Thirty nanograms of purified plasmid DNA was used for sequence analysis. At least eight colonies were sequenced from each transformation. Universal M-13 forward and reverse primers were used as sequence primers. Sequencing was performed at Sanger Sequencing Facility, Frederick National Laboratory for Cancer Research (Frederick, MD).

Animal Procedures. All mice were fed ad libitum with a standard chow diet (NIH31 chow diet; Zeigler Brothers Inc., Gardners, PA). Blood samples from mice fasted for at least 5 hours were collected from the retro-orbital sinus with a heparinized capillary tube (50 or $250 \mu \mathrm{l}$ ) and placed into tubes with EDTA (final concentration $4 \mathrm{mM}$ ). Tubes were centrifuged at $1000 \times g$ for 20 minutes at $4^{\circ} \mathrm{C}$ to obtain plasma. C-II-a peptide was dissolved in saline at a maximum concentration of $10 \mathrm{mg} / \mathrm{ml}$ and injected i.v. into the retro-orbital sinus, i.m. into the thigh muscle of mice, or s.c. into the abdominal area. The maximum volume of the peptide solution used for the injections was $200 \mu \mathrm{l}$ for i.v. and $50 \mu \mathrm{l}$ for i.m. or s.c. injections. One hundred to $165 \mu \mathrm{l}$ of heparin $(0.5 \mathrm{U} / \mathrm{g}$ body weight; Baxter Healthcare Corporation, Deerfield, IL) in saline was injected i.v. in mice that were heparinized.

Immunoblot Analysis. To detect wild-type (WT) and mutant apoC-II in plasma by immunoblot analysis, we first isolated lipoproteins from whole plasma, using lipid removal agent (LRA; calcium silicate hydrate; Supelco 13358-U; Sigma-Aldrich (St. Louis, MO)) (Gordon et al., 2010), with the following modifications. The phospholipid (PL) content in $50 \mu \mathrm{l}$ of plasma from WT, heterozygous, or apoC-II mutant mice was quantitated, and LRA was prepared as a $100-\mathrm{mg} / \mathrm{ml}$ suspension in $1 \times$ phosphate-buffered saline (PBS), pH 7.4. LRA was added to the plasma to give a final ratio of 100:1 mass/mass LRA/PL (i.e., $100 \mu \mathrm{g}$ LRA:1 $\mu \mathrm{g}$ PL). Samples were incubated for 30 minutes at room temperature, mixing slowly and continuously on an endover-end mixer. The samples were then centrifuged at $1000 \times g$ for 2 minutes to pellet LRA-bound lipoproteins, and the supernatants were removed. The LRA-lipoprotein pellet was washed three times with $1 \times$ PBS, pH 7.4, and the supernatants were again removed. To elute lipoproteins from the LRA pellet, $50 \mu \mathrm{l}$ of $1 \times$ loading dye [650 $\mu \mathrm{l}$ $\mathrm{H}_{2} \mathrm{O}, 250 \mu \mathrm{l}$ NuPAGE LDS sample buffer (4×; Invitrogen), $100 \mu \mathrm{l}$ $\beta$-mercaptoethanol] was added to each pellet and mixed by pipetting; samples were then transferred to a small filter unit (UCFCHVNP Ultrafree-MC-HV Centrifugal Filters, Durapore polyvinylidene fluoride, $0.45 \mu \mathrm{m}$, nonsterile; Millipore, Billerica, MA) and centrifuged at $12,000 \times g$ for 3 minutes. The eluted proteins were recovered in the filtrate (eluted fraction) and stored at $-70^{\circ} \mathrm{C}$.

For detection of apoC-II protein levels in the eluted fractions by immunoblotting, an additional $6.25 \mu \mathrm{l}$ of $4 \times$ NuPAGE LDS sample buffer and $2.5 \mu \mathrm{l}$ of $\beta$-mercaptoethanol were added to $16.25 \mu \mathrm{l}$ of each eluted fraction and heated at $95^{\circ} \mathrm{C}$ for 15 minutes before loading onto 
Novex NuPAGE 12\% Bis-Tris gels (Invitrogen) (200 V for 30 minutes in MES buffer), then transferred to polyvinylidene fluoride membranes $\left[0.2-\mu \mathrm{m}\right.$ pore size (Immobilon- $\mathrm{P}^{\mathrm{SQ}}$ ) or $0.45 \mu \mathrm{m}$ pore size (Immobilon-P; Millipore)] at $4^{\circ} \mathrm{C}$ for 3 hours at $200 \mathrm{~V}$ in a Hoefer TE22 transfer tank (Hoefer Inc., Holliston, MA), as described by Freeman (2013)). The membrane was washed $1 \times$ in PBS-T, blocked in Licor Odyssey Blocking Buffer (LI-COR Biosciences, Lincoln, NE) for 1 hour, and then incubated overnight at $4^{\circ} \mathrm{C}$ with $45 \mu \mathrm{l}$ of primary antibody (apoC-II T-12, SC-19015; Santa Cruz Biotechnology, Dallas, TX), diluted to $15 \mathrm{ml}$ in LI-COR Blocking Buffer containing $100 \mu \mathrm{l}$ of $20 \%$ Tween-20. After four washes with PBS-T, blots were incubated at room temperature for 1 hour with the fluorescenceconjugated secondary antibody (IRDye $800 \mathrm{CW}$ donkey anti-goat; LICOR), with $5.0 \mu \mathrm{l}$ of secondary antibody diluted to $15 \mathrm{ml}$ in LI-COR Blocking Buffer containing $150 \mu \mathrm{l}$ of $20 \%$ Tween-20 and $30 \mu \mathrm{l}$ of $10 \%$ SDS. Membranes were washed four times with PBS-T and twice with $1 \times$ PBS, and the bound antibody was visualized using a quantitative fluorescence imaging system (LI-COR) ( $\mathrm{Li}$ et al., 2015).

Plasma Measurements. Fasting plasma lipids were measured by using kits from Wako Pure Chemicals (Osaka, Japan): Total Cholesterol E for total cholesterol (TC), L-Type Triglyceride M for TG (glycerol blank method), Free Cholesterol E for free cholesterol, Phospholipid C for PLs, and NEFA-HR (2) for free fatty acids (FFAs). HDL cholesterol was measured using the Stanbio HDL Cholesterol kit (Stanbio Laboratory, Boerne, TX). Plasma fasting glucose was measured by an enzymatic assay (Glucose HK Gen.3; Roche Diagnostics GmbH, Mannheim, Germany).

For lipoprotein profile analysis, pooled fasting plasma samples (10 $\mu \mathrm{l}, n=3$ mice per group) in each group were applied to an agarose gel (Sebia Hydragel Lipoprotein[e] 15/30; Sebia, Inc., Norcross, GA) and run for 40 minutes at $100 \mathrm{~V}$ using barbital buffer (pH 8.6). Sudan Black was used for lipoprotein staining.

Plasma lipoproteins were also fractionated by fast protein liquid chromatography (FPLC) as described previously (Rousset et al., 2010). Pooled plasma ( $0.25 \mathrm{ml} ; n=3-5$ mice per group) was separated on two Superose 6 columns in tandem (GE Healthcare, Piscataway, NJ) on an AKTA Pure FPLC system (GE Healthcare), and 0.5-ml fractions were collected and analyzed for lipids, as described earlier.

Electron Microscopy Analysis of Lipoproteins. For collection of a lipoprotein fraction enriched in apoB-containing lipoproteins, pooled fasting plasma $(0.25 \mathrm{ml})$ was adjusted with $\mathrm{KBr}$ to a density (d) of $1.063 \mathrm{~kg} / \mathrm{l}$, and a KBr solution $(\mathrm{d}=1.063 \mathrm{~kg} / \mathrm{l})$ was added to the top of the sample to fill the 2-ml tubes. Samples were centrifuged at 100,000 rpm for 24 hours at $5^{\circ} \mathrm{C}$ using an MLA-130 rotor (Beckman Coulter, Fullerton, CA) in a Optima Max Ultracentrifuge (Beckman Coulter). The upper fraction (1.0 ml), containing chylomicrons, very-low-density lipoprotein (VLDL), intermediate-density lipoprotein (IDL), and lowdensity lipoprotein (LDL), was collected to analyze particle sizes by electron microscopy. The samples were prepared by negative staining with $2 \%$ uranyl acetate (Electron Microscopy Sciences, Hatfield, PA) in pure water (w/v) and analyzed on an electron microscope (JEM 1200 EX-II; JEOL, Peabody, MA).

Lipoprotein Proteomic Analysis. Pooled plasma $(0.25 \mathrm{ml}$; $n=3-5$ mice per group) was separated by FPLC, and fractions corresponding to VLDL (elution volumes: 14.0-16.0 ml), LDL $(21.5-24.0 \mathrm{ml})$, and HDL $(27.0-31.0 \mathrm{ml})$ were pooled for analysis. Samples were treated with LRA and processed for trypsinization, as previously described (Gordon et al., 2010). Samples were reconstituted in $20 \mu \mathrm{l}$ of $0.1 \%$ formic acid in water and analyzed by liquid chromatography-tandem mass spectrometry (LC-MS/ MS) on an Orbitrap Velos instrument (Thermo Scientific, Bremen, Germany). To prevent carryover, blank runs were conducted between each sample. Tandem mass spectra were extracted by Proteome Discoverer (version 1.3.0; (Thermo Scientific)). All LCMS/MS samples were analyzed using Mascot (version 1.4.1.14; Matrix Science, London, UK) and X! Tandem [The GPM, thegpm. org; version CYCLONE (2010.12.01.1)] to search the SwissProt database with taxonomy Mus musculus (Sprot_Mus musculus).
Mascot and X! Tandem were searched with a fragment ion mass tolerance of $0.80 \mathrm{Da}$ and a parent ion tolerance of $20 \mathrm{ppm}$. Variable modifications included deamidation, oxidation, carbamidomethylation, and acetylation ( $\mathrm{N}$ terminus). The digest enzyme was set to trypsin with a maximum of two missed cleavage sites. Scaffold (version Scaffold_4.1.1; Proteome Software Inc., Portlant, OR) was used to validate MS/MS-based peptide and protein identifications. Peptide identifications were accepted if they could be established at greater than $5.0 \%$ probability to achieve an False Discovery Rate (FDR) less than $1.0 \%$ by the Scaffold Local FDR algorithm. Protein identifications were accepted if they could be established at greater than $95 \%$ probability and contained at least two identified peptides. Protein probabilities were assigned by the Protein Prophet algorithm (Nesvizhskii et al., 2003). For each sample, spectral counts were normalized to the total spectral counts.

Normalized spectral counts were used to compare the relative abundance of proteins detected in pooled VLDL, LDL, and HDL FPLC fractions. Comparisons were only made within each lipoprotein class among wild-type, heterozygous, and homozygous Apoc2 mutant mice. The results are presented as percent change for each lipoprotein class in the normalized spectral count for each identified protein in the mutant mice compared with wild-type mice.

Matrix-Assisted Laser Desorption/Ionization Time-of-Flight (MALDI-TOF) Measurements of C-II-a. Frozen plasma samples were thawed and diluted $100 \times$ with chilled $0.1 \%$ trifluoroacetic acid (TFA) containing $1.1 \mu \mathrm{g}$ of the 5A-R peptide (DWLKAFYD RVAERLKEAFPDWAKAAYDRAAERAKEAA amino acid sequence, molecular weight $=4330$ ), which was used as an internal standard. Duplicate samples of diluted plasma $(20 \mu \mathrm{l})$ were purified on ZipTip C18 columns (Millipore), according to the manufacturer's instructions and eluted directly onto a $45^{\circ} \mathrm{C}$ AnchorChip target (Bruker, Billerica, MA). Matrix-Assisted Laser Desorption/Ionization Time-of-Flight (MALDITOF) with $5 \mu \mathrm{l}$ of $75 \%$ acetonitrile and $0.1 \%$ TFA. Samples were dried and overlaid with $2 \mu \mathrm{l}$ of saturated sinapinic acid in $50 \%$ acetonitrile and $2.5 \%$ TFA. The target was calibrated with peptide and protein standards (Bruker), and spectra were collected using a Bruker Autoflex III in linear positive mode over an $\mathrm{m} / \mathrm{z}$ range of $2,000-20,000$. Peak areas were used to determine the ratio of sample to $5 \mathrm{~A}-\mathrm{R}$, and each mouse was normalized to the 15-minute time point.

LPL Activity Assay. LPL activity was measured as before by monitoring the generation of FFA (Amar et al., 2015), with some minor modifications. Mouse plasma or human plasma samples (1:250 in a final dilution) and/or $1.0 \mathrm{pmol} / \mu \mathrm{l} \mathrm{C-II-a}$ and/or 0.008 units of LPL purified from bovine milk (Sigma-Aldrich) were added to the wells of a 96-well plate. Total reaction volume was $50 \mu \mathrm{l}$ in phosphate-buffered saline ( $\mathrm{pH} 7.4)$ containing $0.1 \%(\mathrm{w} / \mathrm{v})$ fatty acid-free bovine serum albumin. The samples were incubated for 1 hour on ice and then incubated for another hour at room temperature. Levels of FFA generated from plasma TG were measured by enzymatic assay as described earlier.

Data Analysis. Unless otherwise indicated, all values represent the mean \pm 1 S.D. Comparison between groups was done by one-way analysis of variance with post-hoc Tukey's test. A value of $P<0.05$ was considered to be statistically significant. Prediction of the signal peptide cleavage site was used with web-based software (http:// www.cbs.dtu.dk/services/SignalP/).

\section{Results}

Generation of ApoC-II Mutant Mice. Based on the mouse Apoc2 gene sequence (Hoffer et al., 1993), ZFN constructs were designed to target exon 3 (Fig. 1A). The DNA binding region of each ZFN recognizes $16-18 \mathrm{bp}$, thus restricting the DNA cleavage by the Fok1 nuclease in the region between the two ZFNs, because ZFNs work only as obligatory heterodimers (Carbery et al., 2010; Cui et al., 2011). Of the 41 mice born after microinjection into the pronucleus, 
A ZFN binding/cutting site

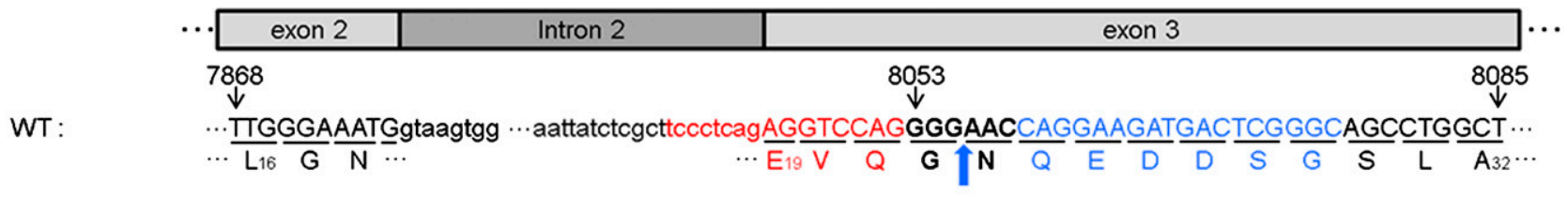

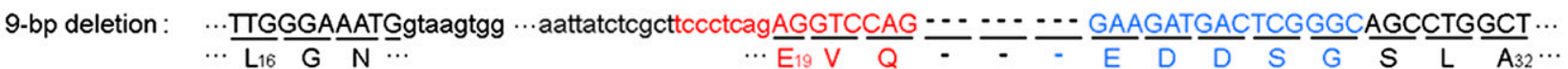

B

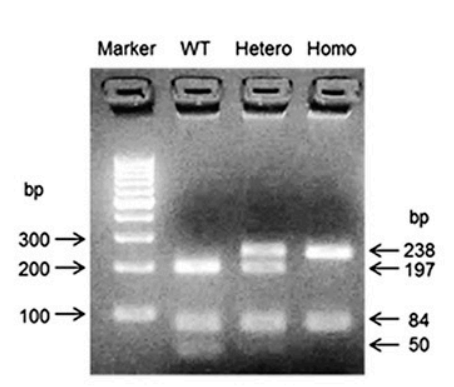

C

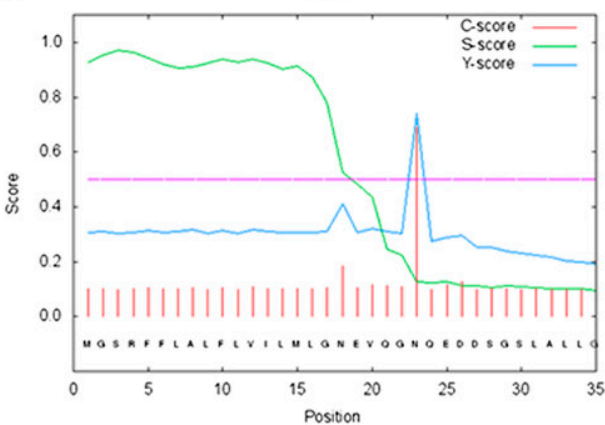

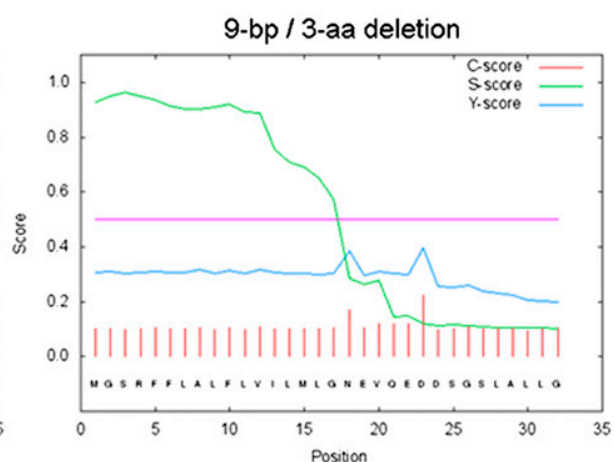

Fig. 1. Targeting strategy of ZFN-mediated targeted genome editing for creating Apoc2 mutant mice. (A) Uppercase and lowercase letters delineate exons and introns, respectively. Bold black letters (GGGAAC), red letters (tccetcagAGGTCCAG), and blue letters (CAGGAAGATGACTCGGGC) indicate the site targeted to cut by FokI and sites for ZFN-1 and ZFN-2 DNA binding, respectively. Numbers above the base indicate nucleotide position for the Apoc2 gene. The amino acid sequences of apoC-II in both WT mice (top) and in mutant mice with a 9-bp deletion in Apoc2 gene and the deletion of 3 amino acids in the mutant protein (bottom) are also shown. Numbers in subscript below each amino acid indicate amino acid position of the prosequence form of protein. Bold blue arrow indicates position of signal peptide cleavage site for WT protein. Dotted lines in the sequence indicate either missing nucleotides or amino acids for the mutant apoC-II protein. (B) A PCR-restriction fragment length polymorphism assay for genotyping of the 9-bp deletion. DNA fragments cleaved by the BspLI restriction enzyme were resolved on a $4 \%$ agarose gel and stained with ethidium bromide. The following bands were observed for the three possible genotypes: 1) WT (50, 84, and $197 \mathrm{bp}), 2$ ) heterozygous mice $(50,84,197$, and $238 \mathrm{bp})$, and 3) homozygous mice (84 and $238 \mathrm{bp}$ ). (C) A cleavable signal peptide site was predicted by online software (SignalP). The C-score (red) was calculated to be high at the position immediately after the (+1) residue, the known cleavage site for the WT protein but not for the mutant protein. The S-score (green) indicates the likelihood of the presence of a signal peptide and was similar for WT and mutant protein. The Y-score (blue) is a composite of the C- and S-scores and indicates the correct cleavage site of the WT sequence but a low likelihood of signal peptide cleavage for the mutant protein (below purple threshold line).

eight mice had biallelic mutations, and eight mice had monoallelic mutations. Of the 34 mice born after microinjection into the cytoplasm, one mouse had biallelic mutations, and three mice had monoallelic mutations. DNA sequence analysis of founder mice with markedly elevated TG (1300-2200 vs. $55.9 \pm 13.3 \mathrm{mg} / \mathrm{dl}$ in wild-type sibling controls) revealed that all of the biallelic mutant mice had a 9-bp deletion (C.8053_8061del) in one allele, resulting in the deletion of three amino acids $\left(\mathrm{G}_{22}, \mathrm{~N}_{23}\right.$, and $\left.\mathrm{Q}_{24}\right)$ (Fig. 1A). Either a 1-bp (C.8055delG) or a 2-bp (C.8055_8056delGA) deletion was found in the other allele, which resulted in two different frameshift mutations with premature stop codons (1-bp deletion: [ $\mathrm{G}_{22}$ TRKMetTRAAWLCWARCRAPS (stop)]; 2-bp deletion: $\left[\mathrm{G}_{22} \mathrm{PGR}\right.$ (stop)]). After repeated attempts to produce homozygous mice for each mutation, we were only able to produce mice that survived weaning for the 9-bp Apoc2 deletion mice. A restriction fragment length polymorphism-PCR screening method for genotyping the 9-bp deletion mice was developed, using BspLI (Fig. 1B). As expected, based on the predicted cut site of BspLI, the following bands were observed for the three possible genotypes: (1) wild type (50, 84, and $197 \mathrm{bp}$ ), (2) heterozygous mice (50, 84, 197, and $238 \mathrm{bp}$ ), and (3) homozygous mice ( 84 and 238 bp) (Fig. 1C).

Effect of 3-Amino Acid Deletion on ApoC-II Levels in Plasma. As shown in Fig. 1A, the 3 -amino acid deletion $\left(\mathrm{G}_{22}\right.$, $\mathrm{N}_{23}, \mathrm{Q}_{24}$ ) for the 9-bp deletion mice was located at the signal peptide cleavage site (Sharpe et al., 1984; Wang, 1991). Residues flanking the signal peptide cleavage site are known to be critical for recognition by the signal peptidases (Auclair et al., 2012). Unlike the wild-type sequence, the mutant sequence with the 3 -amino acid deletion was not predicted to undergo signal peptide cleavage (Fig. 1C). To confirm this prediction, the size of the WT and mutant apoC-II proteins was tested by immunoblot analysis of mouse plasma (Fig. 2A). Plasma from WT mice showed only a signal band with an approximate molecular mass of $8.8 \mathrm{kDa}$, the expected size of mouse apoC-II. In contrast, two bands were observed in heterozygous mice; one band comigrated with the WT apoCII protein, whereas the other band was approximately $1.9 \mathrm{kDa}$ larger, consistent with the retention of the signal peptide. Homozygous mice only showed the higher molecular mass form of apoC-II. Mutant proteins with uncleaved signal peptides are often retained in the endoplasmic reticulum and are poorly secreted (Symoens et al., 2009), but we consistently observed increased amounts of the mutant apoC-II protein compared with the WT protein in plasma from both heterozygous and homozygous mice.

Next, we examined the lipoprotein distribution of the WT and mutant apoC-II protein in the heterozygous 9-bp deletion mice by separating lipoprotein fractions by FPLC (Supplemental Fig. 1) and performing immunoblot analysis (Fig. 2B). WT apoC-II protein was found in nearly equal amounts in 
A WT Hetero Homo

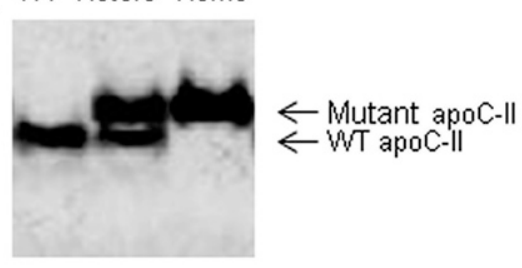

B VLDU

Chylos IDL LDL HDL Albumin
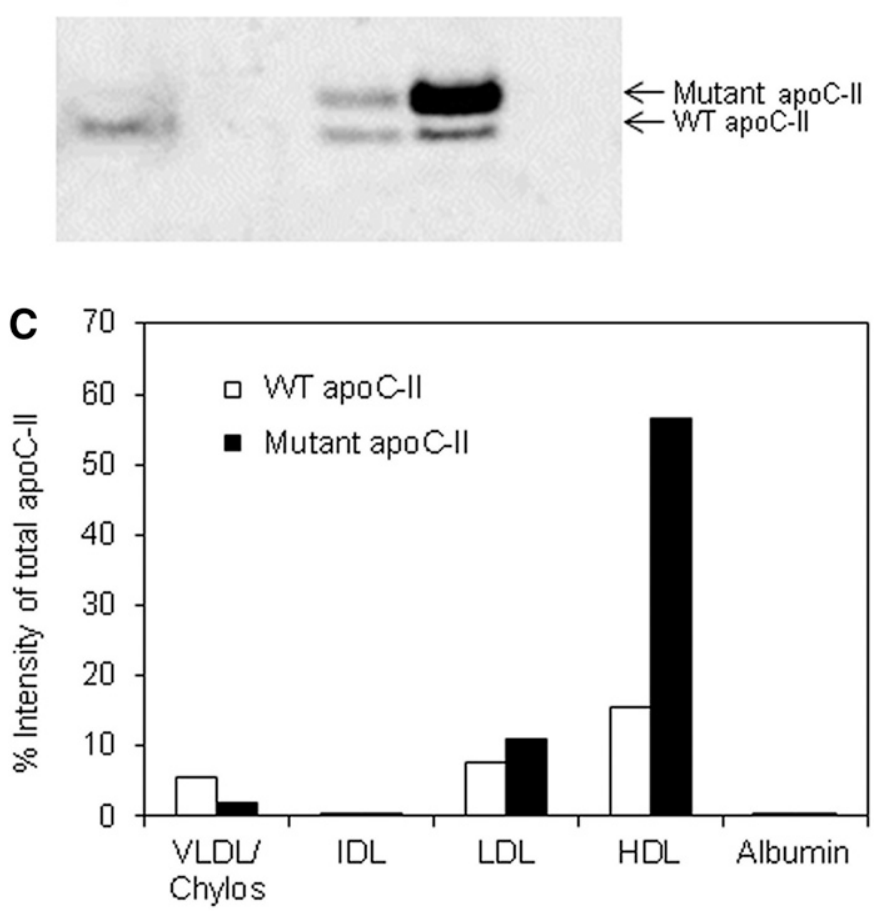

Fig. 2. WT and mutant apoC-II protein abundance and size. (A) Immunoblotting of apoC-II from plasma of three representative individual mice (WT, heterozygous, and homozygous mice). (B) Immunoblotting of apoC-II from FPLC fractions [VLDL/chylos $(20 \mu \mathrm{l})$, IDL $(20 \mu \mathrm{l}), \mathrm{LDL}(7 \mu \mathrm{l})$, HDL $(7 \mu \mathrm{l})$, and albumin $(20 \mu \mathrm{l})$ ] of an apoC-II heterozygous mouse. (C) Quantitation of WT versus mutant apoC-II in FPLC fractions [from (B)] by densitometry, expressed as a percentage of the total signal (WT plus mutant) for apoC-II in all fractions combined. The percentages were corrected for the different volumes applied to the gel.

VLDL, LDL, and HDL, and was not found in fractions corresponding to IDL or in the lipoprotein-free albumin fraction. In contrast, almost undetectable levels of the larger mutant apoC-II protein with the uncleaved signal peptide were found on VLDL, with the vast majority of mutant apoC-II found instead on HDL and to a much small degree on LDL. From a densitometric scan of the gel, we estimate that approximately $80 \%$ of the total mutant apoC-II protein in heterozygous mice was associated with HDL (Fig. 2C).

Analysis of Plasma Lipids. Plasma from homozygous Apoc2 mutant mice with the 9-bp deletion was visibly turbid and had an elevated mean TG of 757.5 $\pm 281.2 \mathrm{mg} / \mathrm{dl}$ (Fig. 3 ), which was similar to plasma TG levels in apoCII-deficient patients (Connelly et al., 1987). Heterozygous mice only had a modest increase in TG $(147.6 \pm 46.2 \mathrm{mg} / \mathrm{dl})$ compared with wild-type sibling controls $(55.9 \pm 13.3 \mathrm{mg} / \mathrm{dl})$. No significant gender differences were observed between mice for TG or other lipid parameters (data not shown).
In addition, homozygous mutant mice had approximately half the level of HDL cholesterol (HDL-C) compared with wild-type siblings, whereas heterozygous mice appeared to have slightly elevated HDL-C when compared with wild-type siblings. No major changes were observed in TC, but the homozygous mice had a significantly higher level of free cholesterol in plasma and a decrease in concentration of esterified cholesterol. As a result, the ratio of esterified cholesterol/TC in plasma was statistically significantly decreased from $86 \%$ to $65 \%$, which indicates a possible decrease in the efficiency of cholesterol esterification.

Analysis of Plasma Lipoproteins. As expected, FPLC analysis demonstrated that almost all of the plasma cholesterol in wild-type sibling control mice was found in HDL (Fig. 4A), and only a small peak of TG was observed in fractions corresponding to VLDL or chylomicrons. In contrast, the homozygous 9-bp deletion mice had a marked increase of TG in fractions corresponding to VLDL and chylomicrons, and a smaller peak of cholesterol in HDL size fractions (Fig. 4C). Heterozygous mice showed an intermediate phenotype. Consistent with the observed increase in HDL-C (Fig. 3), more cholesterol was observed in the HDL peak from heterozygous mice (Fig. 4B) compared with wild-type mice (Fig. 4A).

Overall, similar results were found when lipoproteins were analyzed by agarose gel electrophoresis (Fig. 4D), but it appeared that the majority of the increase in TG-rich lipoproteins in homozygous mice was due to an increase in VLDL. Only a relatively small increase in staining was observed near the origin of the gel, where nascent chylomicrons typically migrate.

We further characterized the TG-rich lipoproteins that accumulate in the Apoc2 mutant mice by isolating lipoproteins with a density $<1.063 \mathrm{~g} / \mathrm{ml}$, using density gradient ultracentrifugation, followed by negative staining electron microscopy (Fig. 4E). The predominant lipoprotein particle size observed in wild-type mice was approximately $20-22 \mathrm{~nm}$ in diameter, the reported size of LDL. Rarely, larger lipoprotein particles with a diameter between 30 and $60 \mathrm{~nm}$, consistent with VLDL, were also observed. In homozygous Apoc2 mutant mice, much larger particles between 30 and $140 \mathrm{~nm}$ were more frequently observed than in wild-type mice, and most likely represent incompletely lipolyzed lipoproteins, such as large VLDL, IDL, or chylomicron remnant particles. In addition, we noted that Apoc2 mutant mice also had relatively more small dense LDL, with an average diameter of about 18-19 $\mathrm{nm}$ (data not shown). Based on the analysis of the lipoprotein particle size distribution (Fig. 4F), homozygous mutant mice show an approximate 7 -fold increase in the percentage of the total number of lipoprotein particles over $30 \mathrm{~nm}$ [42.4\% (homozygous) vs. $6.2 \%$ (WT) of total counts].

Proteome Analysis of Lipoproteins. We next examined the proteome composition by LC-MS/MS analysis of VLDL/ chylos, LDL, and HDL size particles isolated by FPLC (Fig. 5). In the VLDL/chylos fraction isolated from homozygous Apoc2 mutant mice, the levels of apoA-IV, apoA-I, apoC-III, apoA-II, and apoC-I were markedly increased by $1280 \%, 930 \%, 450 \%$, $310 \%$, and $300 \%$, respectively. Several of these proteins, such as apoC-III, apoA-II, and apoC-I, are known to inhibit LPL (Ito et al., 1990; Boisfer et al., 1999; van der Hoogt et al., 2006) and thus may contribute to the hypertriglyceridemic phenotype in these mice. In contrast, several proteins-namely, apoE, apoB, apoM, apoJ, and histidine-rich glycoprotein-were 

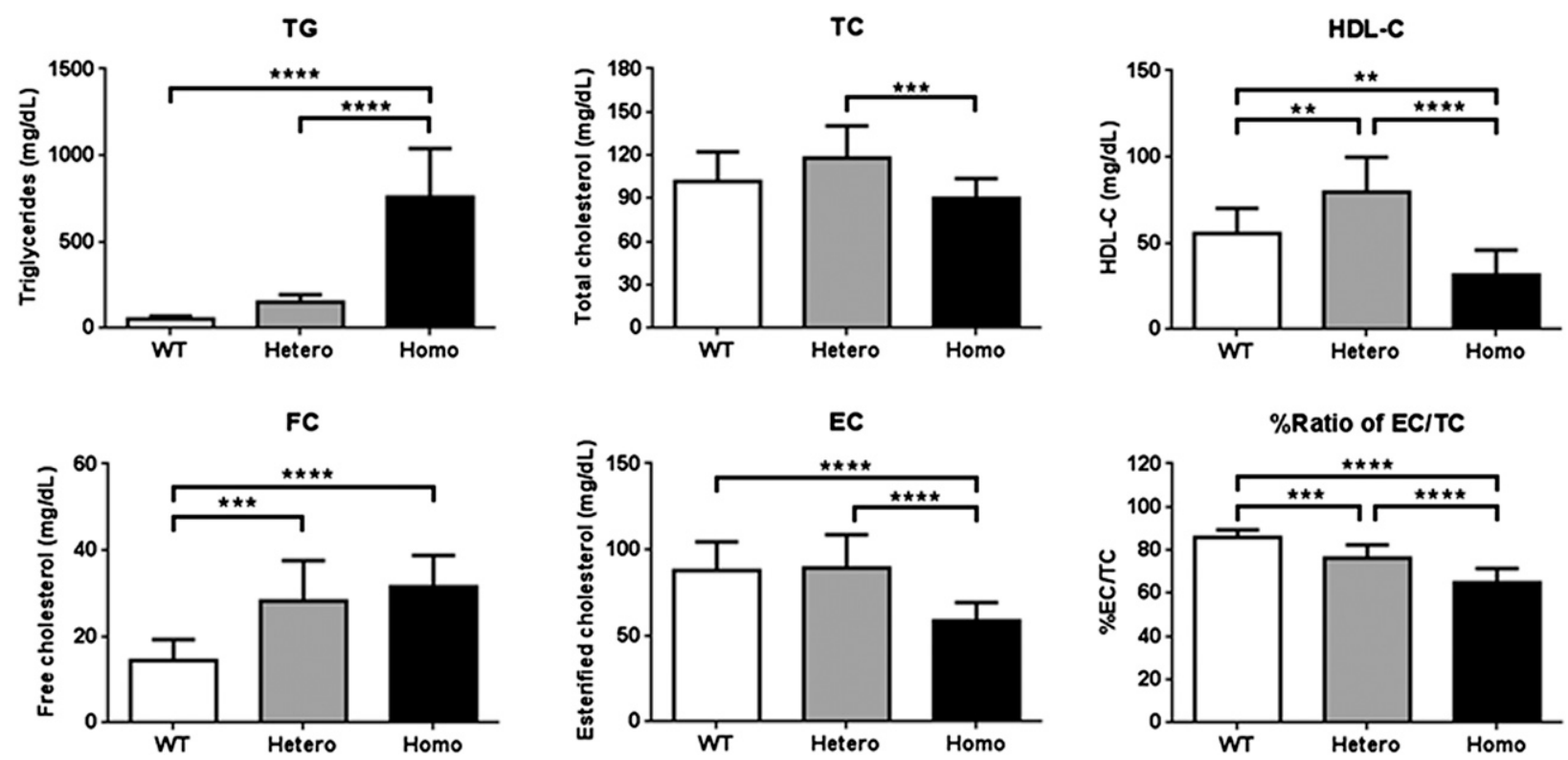

Fig. 3. Effect of Apoc2 9-bp deletion on plasma lipids. A 5-hour fasting plasma was obtained from 2-month-old mice ( $n=10-19$ per groups). Results are represented as the mean \pm S.D. ${ }^{* *} P<0.01$; $* * * P<0.005$; ****P $<0.0001$. EC, esterified cholesterol; FC, free cholesterol.

decreased on VLDL/chylos from homozygous Apoc2 mutant mice. A decrease in the ApoE content of these lipoprotein particles would be expected to delay their clearance from the plasma and could also contribute to the hypertriglyceridemia in these mice. It is also known that, in Apoe-deficient mice, apoA-I is shifted from HDL to other lipoprotein fractions, and that the level of HDL-C is significantly decreased (Thorngate et al., 2003). We observed a similar redistribution of apoA-I from HDL to VLDL and decreased levels of HDL-C (Fig. 3) in our apoC-II mutant mice. Interestingly, we also observed a marked increase in the level of histidine-rich glycoprotein (Vu et al., 2015) on HDL in the apoC-II mutant mice and a corresponding loss of this protein on VLDL. However, the functional significance of this change and some other protein changes observed on HDL is not known. No major differences were observed in the proteome content of LDL between the three different genotypes (data not shown).

C-II-a Enhances In Vitro Lipolysis. To determine the possible impact of C-II-a, an apoC-II mimetic peptide (Amar et al., 2015), on hydrolysis of TG in the Apoc2 mutant mice, we first assessed the effect of the peptide using an in vitro lipolysis assay (Fig. 6). LPL or LPL plus C-II-a was added to plasma from Apoc2 mutant mice or to human plasma from a patient with apoC-II deficiency (Amar et al., 2015) as a control, and the generation of FFA was measured. As expected, when LPL was added to human serum from the patient with apoC-II deficiency, no further increase in FFA was noted, indicating the requirement of apoC-II as a cofactor for LPL. In contrast, when both LPL and C-II-a were added, a marked increase in the generation of FFA was observed. When LPL was added to homozygous apoC-II mutant mouse plasma, FFA levels increased by about 1.8 -fold, but a much larger increase (3.6-fold) was observed when both LPL and C-II-a were added. Overall, these findings indicate that the mutant mice plasma contains some residual apoC-II activity for activating LPL, and that C-II-a can also activate LPL in human plasma with a different apoC-II mutation besides the one produced in the mice.
C-II-a Enhances In Vivo Lipolysis. Three different doses of C-II-a peptide $(0.2,1$, and $5 \mu \mathrm{mol} / \mathrm{kg}$ of body weight $)$ were injected intravenously into Apoc2 mutant mice, and plasma lipids were monitored over time (Fig. 7A). All doses of C-II-a resulted in a rapid and marked reduction of plasma TG in a dose-dependent manner, with a maximum decrease of approximately $90 \%$ for the high-dose injection after 30 minutes. Plasma TG did not return to baseline until 48 hours post injection. Plasma total cholesterol was also decreased by $40-70 \%$ at 4 hours in a dose-dependent manner, and returned to baseline by 24 hours. FFA also decreased by $70 \%$ at 30 minutes after injection of the peptide, and remained slightly suppressed by $20-40 \%$ even after 48 hours. More complicated time-dependent changes were observed for HDL-C after peptide treatment. For only the highest dose of the C-II-a peptide, a transient decrease in HDL-C was observed by 8 hours, but it later increased by approximately $50 \%$ by 24 hours. For the two lower doses of the peptide, no acute drop in HDL-C was seen, but the later increase in HDL-C at 24 hours was observed.

By FPLC analysis (Fig. 7B), most of the changes in plasma TG following treatment with the high-dose C-II-a peptide were due to changes in VLDL. A marked and sustained decrease in VLDL-TG was observed after the peptide treatment. A similar but less-profound decrease in cholesterol on VLDL was also observed after C-II-a treatment, as was a transient decrease in cholesterol on HDL, all of which returned to baseline by $24-48$ hours.

To determine whether the sustained decrease in TG after C-II-a treatment was potentially due to the long plasma half-life of the peptide or possibly the time needed for the production of new TG-rich lipoproteins, we measured the half-life of C-II-a by Matrix-Assisted Laser Desorption/ Ionization Time-of-Flight Mass Spectrometry (MALDI-TOF MS (Fig. 8A). C-II-a was found to undergo monoexponential decay with an estimated plasma half-life of approximately $1.33 \pm$ 0.72 hours. Only a relatively small amount of peptide was detected 


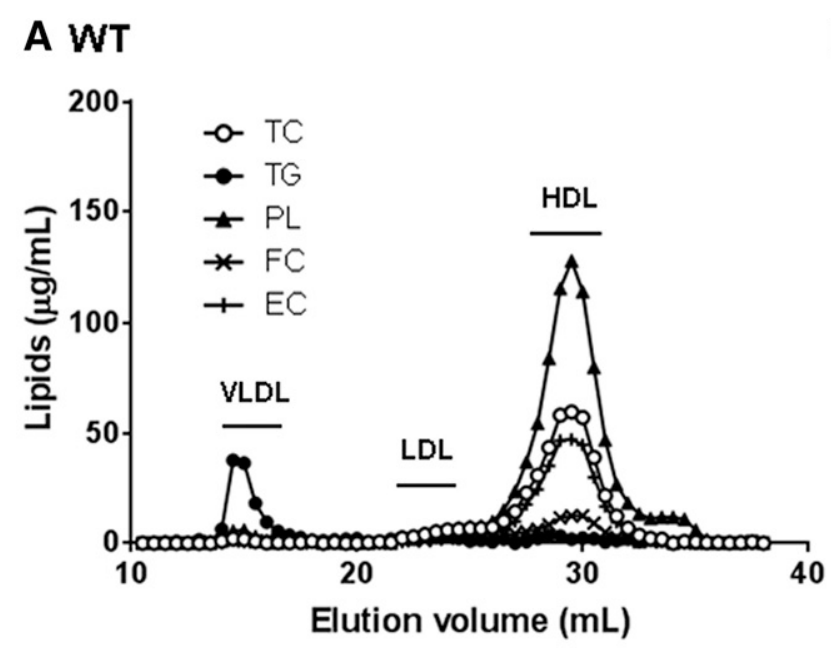

C Homo

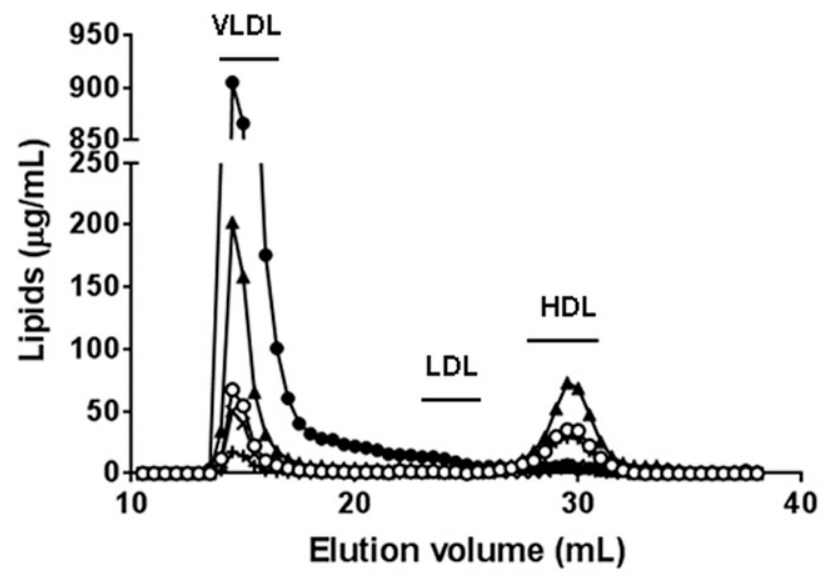

B Hetero

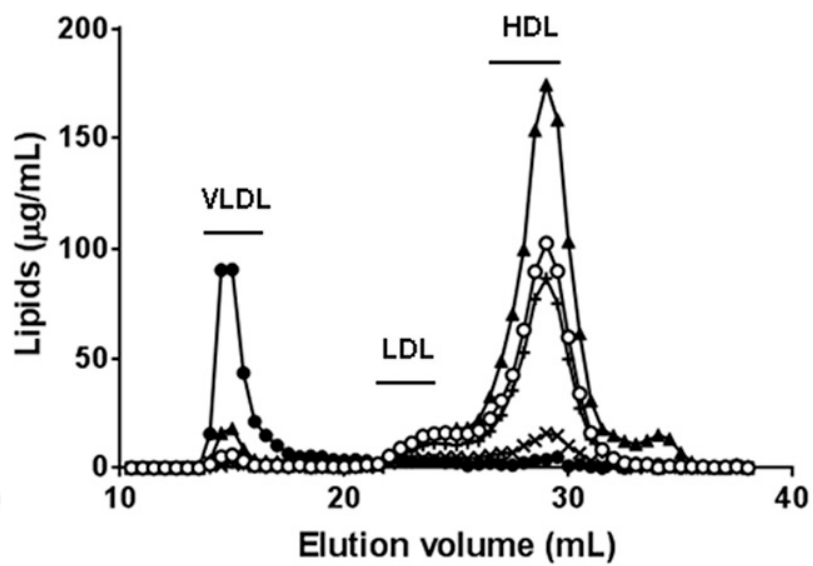

D

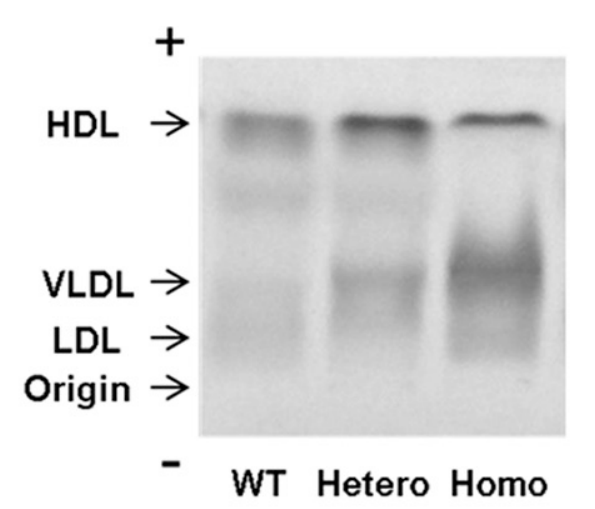

E

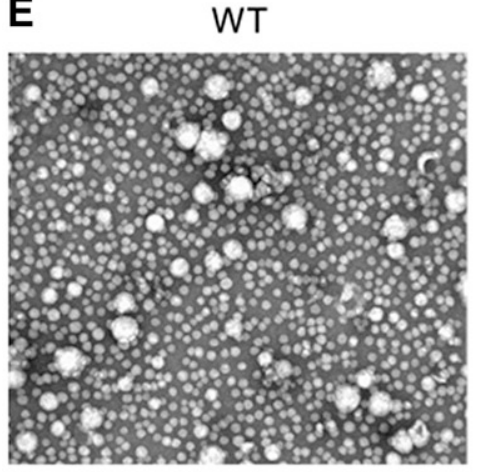

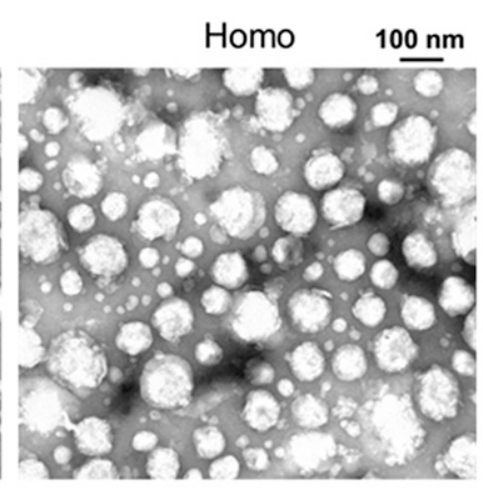

$\mathbf{F}$

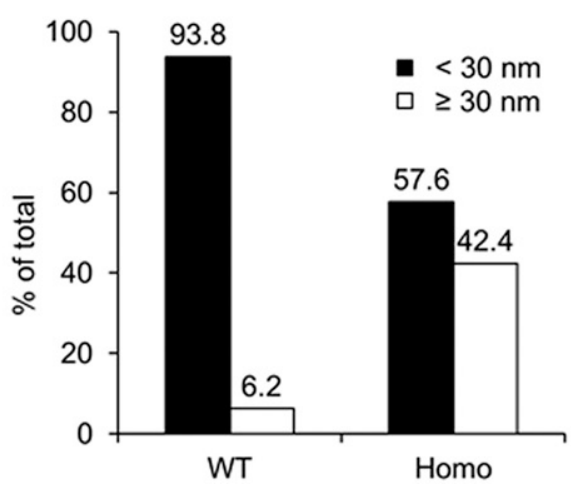

Fig. 4. Analysis of lipoprotein profiles by FPLC (A-C), agarose gel electrophoresis (D), and electron microscopy (E) in Apoc2 mutant mice. For (A), (B), and (C), pooled, 5-hour-fasting plasma $(0.25 \mathrm{ml} ; n=3-5$ per group) was separated by FPLC. (A) WT sibling control mice. (B) Apoc2 heterozygous mutant mice. (C) Apoc2 homozygous mutant mice. (D) Pooled fasting plasma samples (10 $\mu \mathrm{l} ; n=3-5$ per group) were analyzed by Sebia Hydragel lipoprotein(e) gel electrophoresis, followed by Sudan Black staining. (E) A lipoprotein fraction enriched in chylomicrons, VLDL, IDL, and LDL was isolated by ultracentrifugation $(\mathrm{d}<1.063 \mathrm{~kg} / \mathrm{l})$ of plasma from mice $(n=3-5)$ to analyze lipoprotein particle size by electron microscopy. (F) Distribution of lipoprotein particle size greater than and less than $30 \mathrm{~nm}$ was presented as a percentage of total lipoprotein particle counts. EC, esterified cholesterol; FC, free cholesterol.

in the plasma 7 hours after injection, when TG was still decreased. This suggests that the C-II-a peptide only acutely lowers TG, and that it takes approximately 2 days for the secretion of TG-rich lipoproteins to return plasma TG to baseline in apoC-II mutant mice. Another possibility is that the C-II-a peptide may not be in the circulation, but is perhaps attached to lipoproteins bound to the surface of endothelial cells where it could still activate LPL. We tested this possibility by the i.v. injection of heparin solution ( $0.5 \mathrm{U} / \mathrm{g}$ of body weight) at 6.5 hours to displace any endothelial-bound C-II-a peptide but did not observe any increase in the plasma levels of the peptide after the heparin injection (Fig. 8B). Furthermore, the kinetics for the decay of the peptide before and after the heparin injection were similar to what we observed in the mice not treated with heparin. 
A VLDL

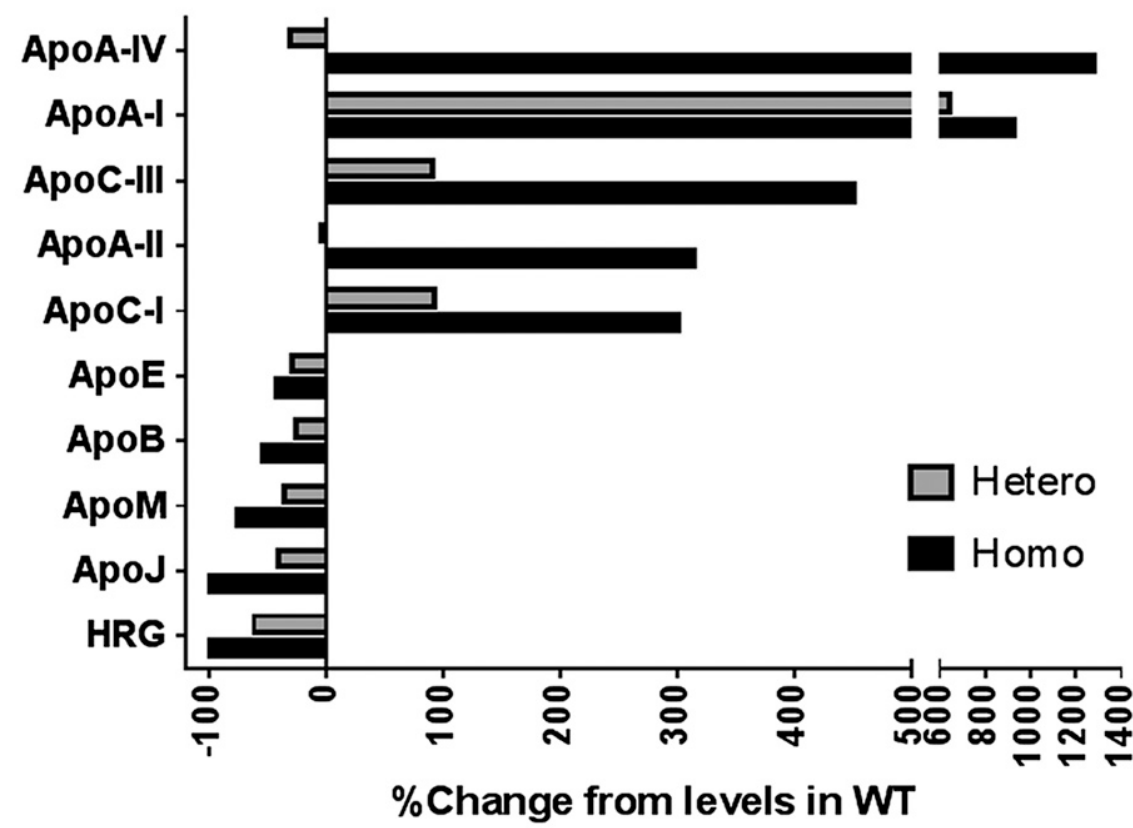

B

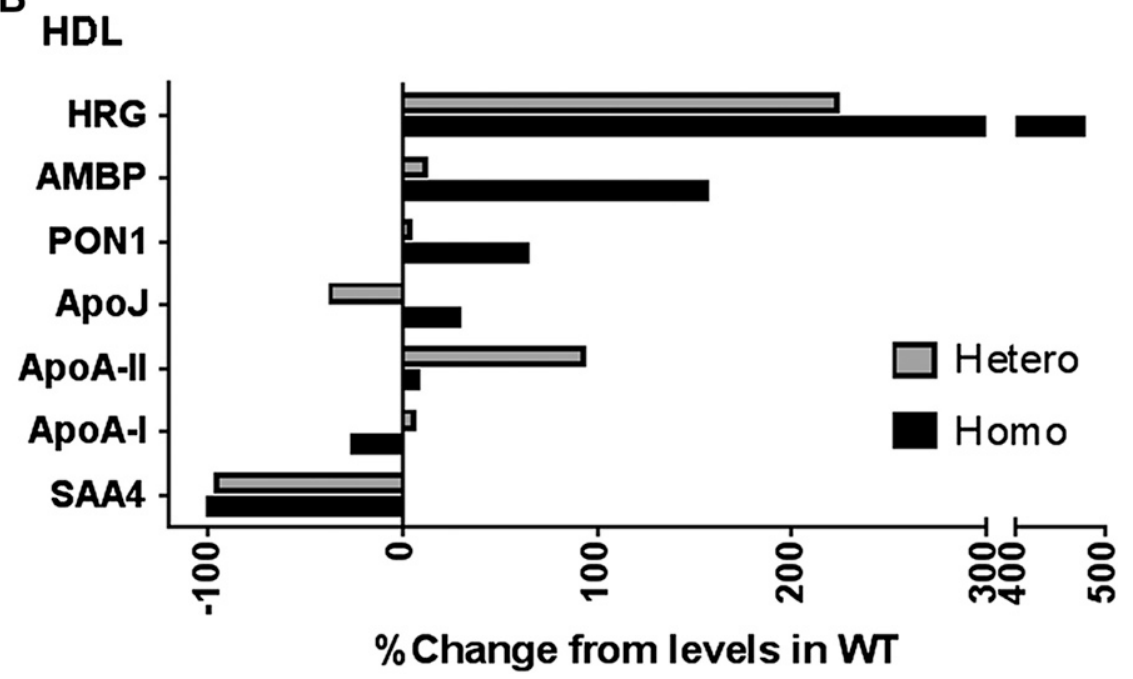

Fig. 5. Proteome contents of lipoprotein fractions. Pooled plasma ( $0.25 \mathrm{ml} ; n=3-5$ per group) was separated by FPLC, as shown in Fig. 4, A-C. Fractions corresponding to VLDL (elution volumes: 14.0-16.0 ml), LDL (21.5-24.0 ml), and HDL $(27.0-31.0 \mathrm{ml})$ were pooled for analysis. Lipid-bound proteins were isolated by LRA, trypsinized, and then analyzed by LC-MS/MS. For each sample, individual spectral counts for each protein were normalized to the total spectral count. The results are presented as the percent change in normalized spectrum counts for each identified protein in the mutant mice compared with the wild type for each lipoprotein class. HRG, histidine-rich glycoprotein.

Finally, we investigated whether other routes of peptide injection-namely, i.m. or s.c.-could also be used to lower plasma lipids in apoC-II mutant mice (Fig. 9). Independent of the route of administration, we observed very similar timedependent decreases for both plasma TG and cholesterol, suggesting that the pharmacodynamic change in lipids caused by the C-II-a peptide injected by i.m. or s.c. routes is similar to the i.v. route.

\section{Discussion}

The first genetic mouse model developed for hypertriglyceridemia was $L p l$-KO mice (Weinstock et al., 1995). Heterozygous $L p l$-KO mice were viable and had plasma TG levels of approximately $120 \mathrm{mg} / \mathrm{dl}$, but homozygous-KO mice died shortly after birth. It was suggested that, because mice have much higher levels of TG in their milk in comparison with humans, newborn mice are much more dependent on TG as an energy source, and thus homozygous $L p l$-KO mice are not able to survive long after birth. Although we were able to obtain homozygous apoC-II KO mice with a 9-bp deletion, we were unable to obtain homozygous mice with a 1- or 2-bp deletion, which results in a frameshift mutation and premature termination of apoC-II. These results suggest that, similar to homozygous $L p l$-KO mice, a complete loss of Apoc 2 may also be lethal in mice. Whether other features that can develop with genetic apoC-II deficiency, such as pancreatitis and hepatosplenomegaly, will develop in the 9-bp deletion mice is not known at this time, but may require the development of a complete conditional knockout mouse for apoC-II.

When we examined plasma from the 9-bp deletion mice by immunoblots (Fig. 2), we observed that the mutant apoC-II protein was larger in size, consistent with the retention of the signal peptide. The signal peptide of Apoc2 contains the classic tripartite structure of eukaryotic signal peptides (Fig. 1). It has one positively charged arginine residue in its first five 


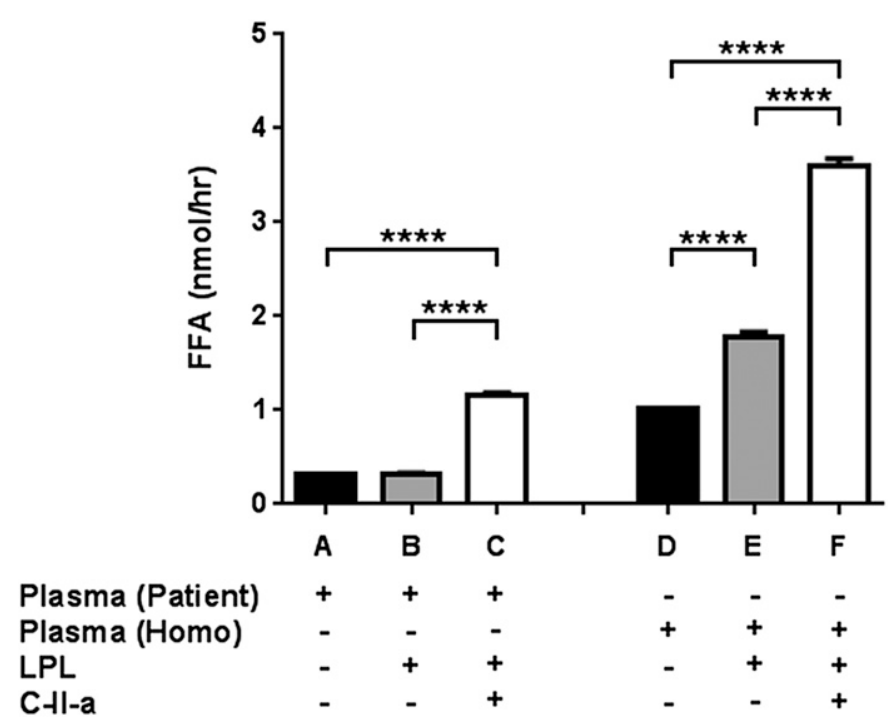

Fig. 6. Effects of C-II-a on in vitro lipolysis. Pooled plasma from homozygous Apoc2 mutant mice $(n=3$; mean \pm S.D. of plasma TG: $627.5 \pm 76.7 \mathrm{mg} / \mathrm{dl}$ ) or human plasma from an apoC-II-deficient patient (TG: $658 \mathrm{mg} / \mathrm{dl}$ ) was incubated in vitro with LPL alone or in combination with C-II-a, and the production of FFA was measured. Results are represented as the mean of triplicates \pm S.D. $* * * * P<0.0001$.

residues followed by a very hydrophobic stretch of 14 amino acids. The canonical consensus just before the cleavage site for the signal peptidase is Ala-X-Ala, but unlike prokaryotes, other small nonpolar amino acids are often found in positions -3 and -1 for eukaryotes. In fact, Val and Gly, the two amino acids found in mouse apoC-II, are the second most common amino acids found in these two positions (Hiller et al., 2004; Choo and Ranganathan, 2008). In the 9-bp deletion mice, these residues are replaced with Gln and Glu, which are not predicted to form a signal peptide cleavage site (Fig. 1). Mutations leading to the retention of signal peptides often interfere with protein secretion, because the hydrophobic signal peptide binds to lipids in endoplasmic reticulum membranes (Jarjanazi et al., 2008). In the case of ApoC-II, perhaps because it associates with lipoproteins, the retained signal peptide could instead bind to lipids on the lipoprotein particle and thereby be secreted normally. A similar mechanism has been proposed for the secretion of apoM (Xu and Dahlbäck, 1999), which naturally has an uncleaved signal peptide.

Besides being larger in size, more mutant apoC-II protein was observed in plasma from the apoC-II mutant mice than WT protein (Fig. 2). The fact that these mice are hypertriglyceridemic, despite the overall higher levels of apoC-II protein, indicates that the mutant form of this protein with the signal peptide must be less effective than WT apoC-II in activating LPL, which is consistent with the results of the in vitro lipolysis assay (Fig. 6). It is possible that the presence of the signal peptide somehow affects the interaction of the third helix of apoC-II with LPL. A more likely and simple explanation, however, is that the altered distribution of the mutant apoC-II protein accounts for the hypertriglyceridemia. Almost all of the TGs in the apoC-II mutant mice were found on VLDL and chylomicrons (Fig. 4), but these lipoprotein fractions were not found to contain significant amounts of the mutant apoCII protein, and hence this would be expected to lead to less effective lipolysis. The majority of the mutant apoC-II protein was instead found on HDL, which is relatively devoid of TG.
Other proteins with normally uncleaved signal peptides, such as paraoxonase 1 (Sorenson et al., 1999), apoM (Xu and Dahlbäck, 1999), and haptoglobin-related protein (Harrington et al., 2014), are also enriched on HDL. The reason for this is not well understood, but it may be that the high radius of curvature in HDL creates phospholipid packing defects (Vedhachalam et al., 2007; Harrington et al., 2014), which more readily allows the insertion of hydrophobic signal peptides into the hydrophobic lipid core of HDL.

In addition to alterations in TG-rich lipoproteins, abnormalities in HDL were also observed in the apoC-II mutant mice. Homozygous mutant mice with the 9-bp deletion had significantly lower levels of apoA-I and HDL-C (Figs. 3 and 5). It is known that ApoA-I is a potent activator of LCAT, an HDLassociated enzyme that esterifies cholesterol. This could account for the observed increase in the level of unesterified free cholesterol and the decrease in HDL-C (Fig. 3). It has been previously reported that humans with apoC-II deficiency also have decreased levels of esterified cholesterol on HDL (Dumon and Clerc, 1986), possibly because of decreased LCAT activity (Karpe et al., 1990). Hypertriglyceridemia, in general, has also been found to be associated with decreased cholesterol esterification (Eisenberg et al., 1984) and to accelerate the catabolism of HDL (Brewer, 1999; Rashid et al., 2003), which could also contribute to the low HDL-C seen in the homozygous mice. In contrast, heterozygous mice with only a small increase in TG had a modest but statistically significant increase in HDL-C. It may be that the elevation of TG in the heterozygous mice was not enough to substantially lower HDL-C by the aforementioned mechanisms, and that the partial loss of LPL activity led to increased HDL-C because LPL, similar to hepatic lipase, may partially act on HDL to lower its level (Rashid et al., 2003). Whether other features that can develop with genetic apoC-II deficiency, such as pancreatitis and hepatosplenomegaly, will develop in the 9-bp deletion mice is not known at this time, but may require the development of complete conditional knockout mice for apoC-II.

Currently, there is no specific therapy for apoC-II-deficient patients. Similar to other patients with genetic causes of hypertriglyceridemia, they are usually managed by treatment with low-fat diets (Wilson et al., 2003). High-carbohydrate foods should also probably be avoided to limit the hepatic conversion of excess carbohydrates into endogenous triglycerides (van de Woestijne et al., 2011; Boullart et al., 2012). Previously, we showed that the C-II-a peptide restored lipolysis when added along with LPL to plasma from a patient with apoC-II deficiency (Amar et al., 2015), suggesting that it could be a possible therapy for this disorder. In this study, we tested the feasibility of using the C-II-a peptide as a therapy by testing it in apoC-II mutant mice. We found that relatively low doses of C-II-a rapidly lowered plasma triglycerides by over $90 \%$ within 30 minutes of administration (Fig. 7A). It also lowered total cholesterol, but to a lesser degree. At higher doses of the peptide, we did observe a transient lowering of HDL-C, but higher levels of HDL-C were observed at later time points (Fig. 7A), which is most likely due to the overall lowering of TG. Interestingly, despite the increase in the lipolysis of TG, we observed a marked decrease in FFA after treatment with the C-II-a peptide (Fig. 7A). This suggests that C-II-a most likely enhanced lipolysis by LPL bound to endothelial cells, which permits very efficient removal of FFA by peripheral tissues (Kamp et al., 2003; Goldberg 
A

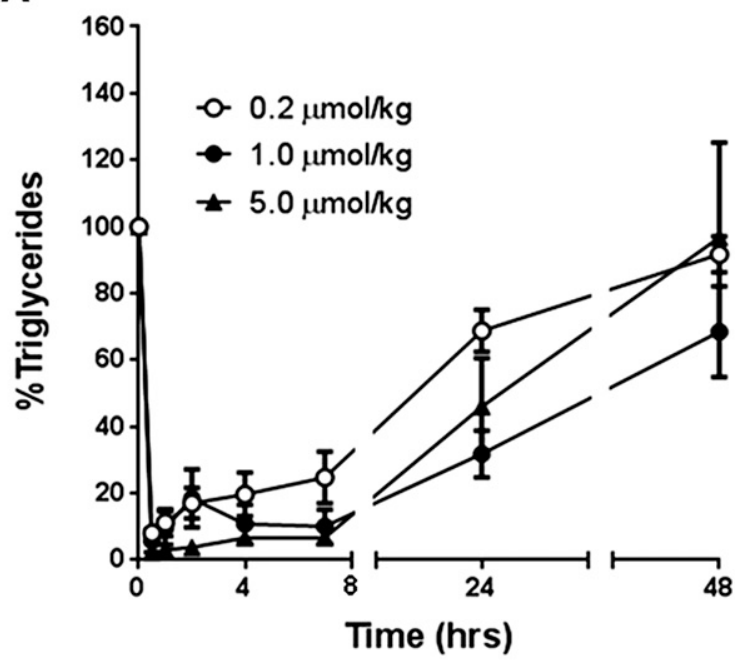

FFA

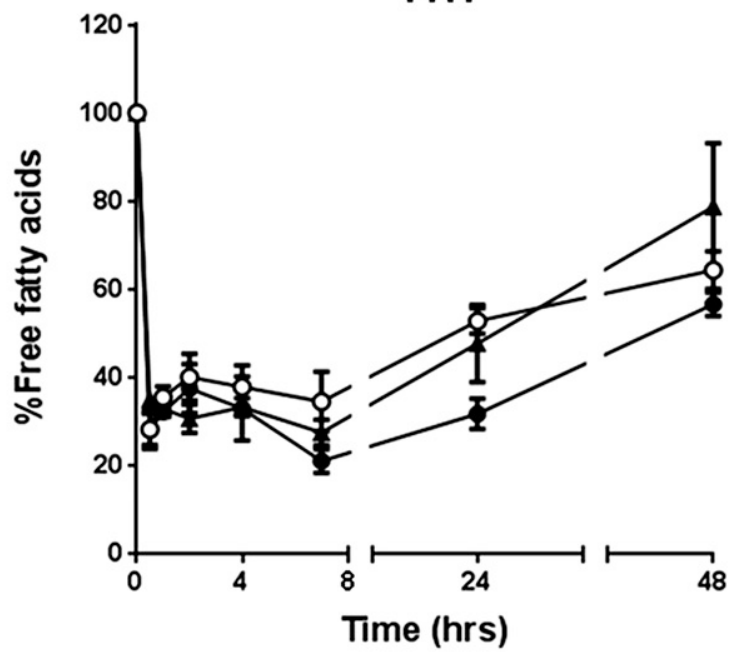

B

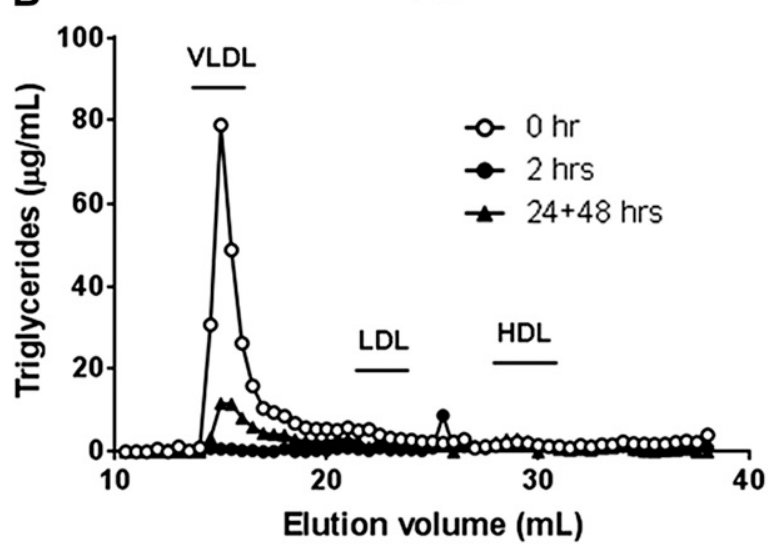

TC

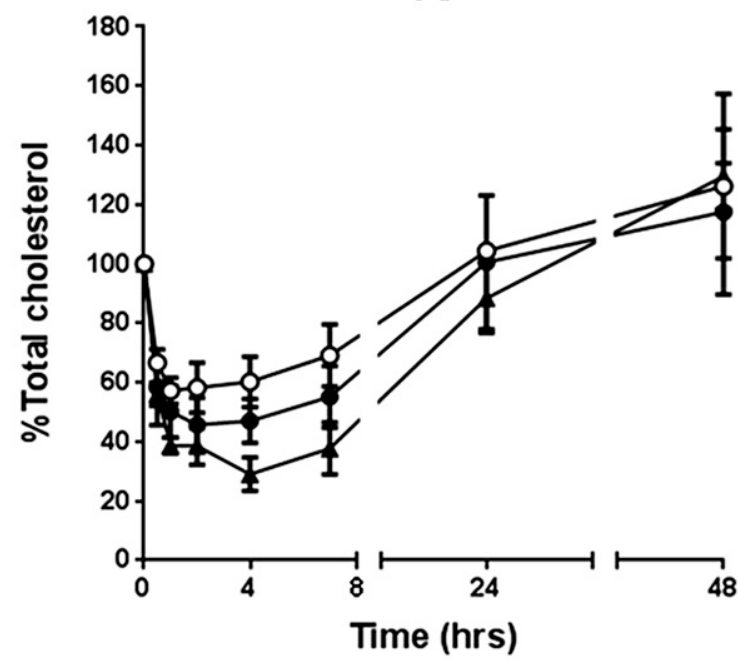

HDL-C

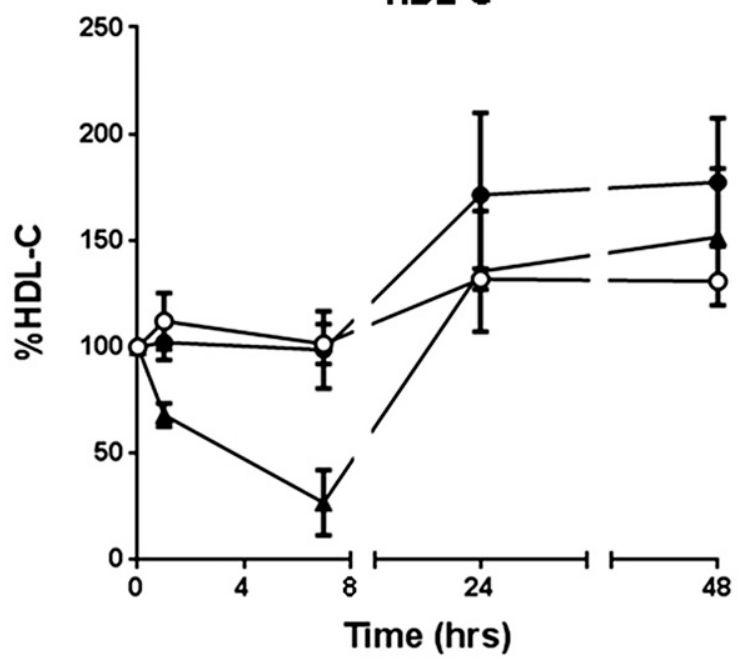

TC

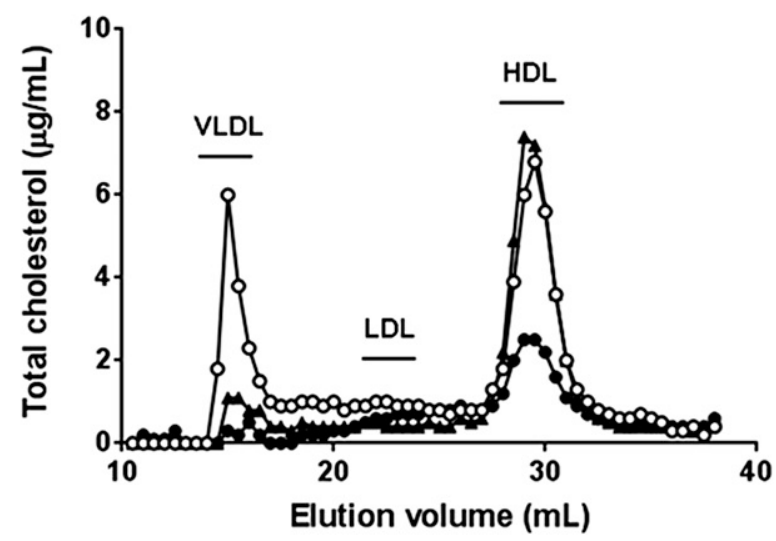

Fig. 7. Effects of i.v. injection of C-II-a into Apoc2 mutant mice. (A) Analysis of plasma lipids. 200 microliters of C-II-a peptide ( $0.2,1.0$, and $5.0 \mu$ mol/kg of body weight) was injected into the retro-orbital sinus of Apoc 2 mutant mice $(n=3$ per groups). Lipid levels were measured in the plasma at $0,0.5,1,2,4,7,24$, and 48 hours after C-II-a injection. Data are the mean \pm S.E.M. (B) Distribution of lipids in plasma analyzed by FPLC. 50 microliters of plasma pooled from three mice was separated by FPLC. The level of TC and TG in the fractions was measured at $0,2,24$, and 48 hours after C-II-a injection (5.0 $\mu$ mol/kg of body weight).

et al., 2009). In fact, FFA levels typically decrease in the postprandial state, when LPL is most active. The majority of FFA in the plasma is first generated intracellularly by adipocyte lipolysis, which is then released into the circulation (LeRoith et al., 2003). In fact, increased intracellular accumulation of fat in adipocytes, which occurs as a consequence of 

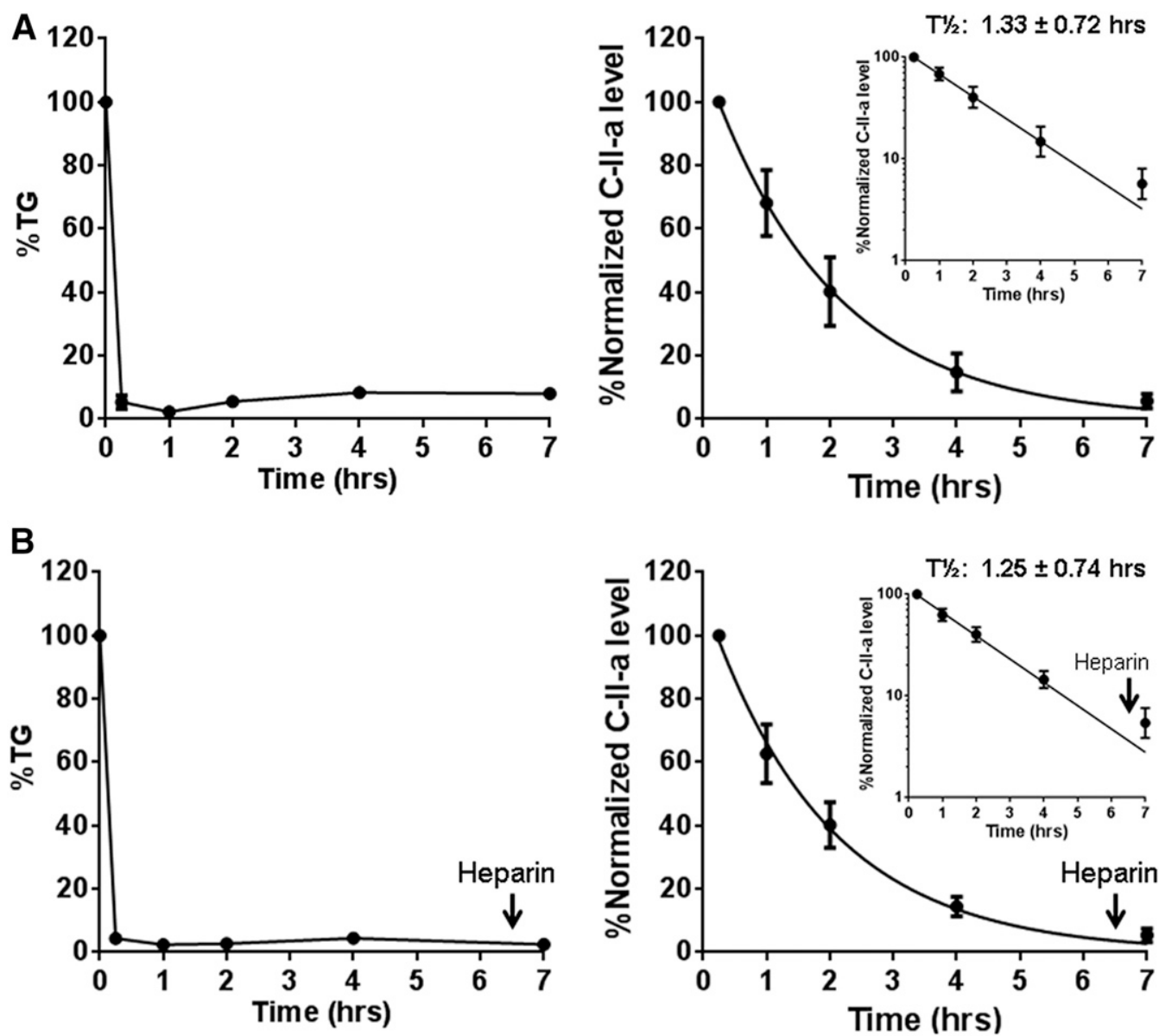

Fig. 8. Decreased TG and C-II-a in Apoc2 mutant mice after i.v. injection of C-II-a. (A) Changes in plasma levels of TG and C-II-a after C-II-a injection. C-II-a was injected into four Apoc 2 mutant mice ( $5.0 \mu \mathrm{mol} / \mathrm{kg}$ of body weight). C-II-a concentrations in plasma were analyzed by Matrix-Assisted Laser Desorption/ Ionization Time-of-Flight Mass Spectrometry (MALDI-TOF MS) using 5A-R peptide solution (molecular weight 4330) as an internal standard. Data shown are the mean \pm S.E.M. (B) The change of plasma levels of TG and C-II-a after heparin injection (0.5 U/g of body weight) at 6.5 hours after the C-II-a injection. Data shown are the mean \pm S.E.M. (Insets) Half-time of C-II-a without (A) or with (B) heparin injection at $t=6.5$ hours after log transformation of the $y$-axis.

lipolysis by LPL, promotes storage of triglycerides and inhibits intracellular lipolysis and release of FFA into the circulation (Guilherme et al., 2008). This probably accounts for the prolonged decrease in plasma FFA levels after the C-II-a peptide treatment, which persisted even 48 hours later when serum TG returned to baseline (Fig. 7).

The half-life of the C-II-a peptide was estimated to be $1.33 \pm$ 0.72 hours (Fig. 8A). Thus, the relatively long time delay of
2 days for TG to return to baseline after peptide treatment was most likely related to the time needed for the new synthesis of TG-rich lipoproteins. The half-life of the peptide, however, is sufficiently long that it could possibly be used to lower TG in the postprandial period. The fact that similar pharmacodynamic changes in serum lipids were observed independent of the route of administration (Fig. 9) suggests that it may be possible in the future for patients with apoC-II deficiency to
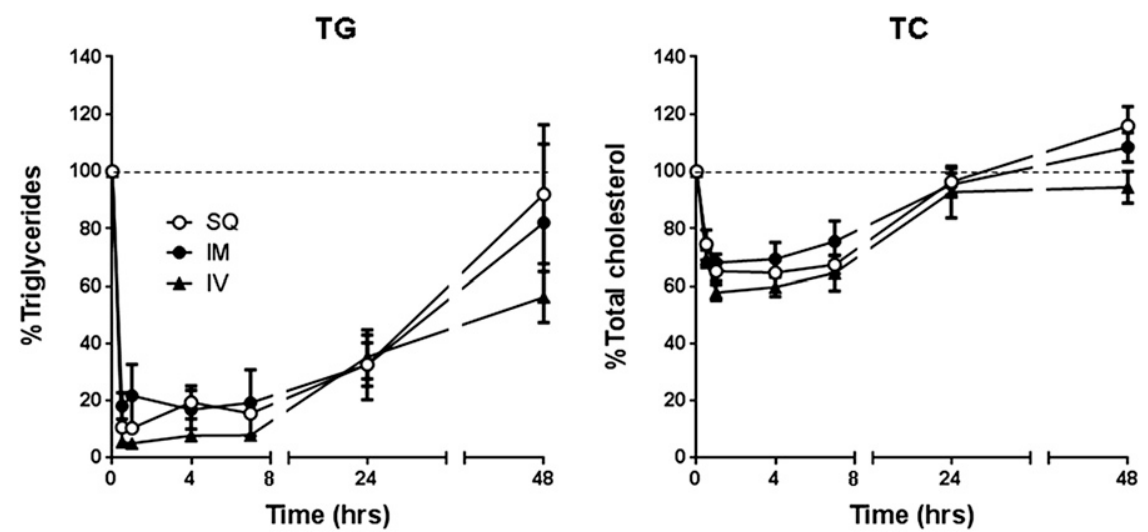

Fig. 9. Effects of different routes of C-II-a administration on plasma lipids in Apoc2 mutant mice. 50 microliters of C-II-a peptide $(1.0 \mu \mathrm{mol} / \mathrm{kg}$ of body weight) was injected subcutaneously (SQ) into the abdomen, intramuscularly (IM) into the thigh muscle, or intravenously (IV) to the retro-orbital sinus of Apoc2 mutant mice ( $n=3$ per groups). Plasma TC and TG levels were measured at $0,0.5,1,4,7,24$, and 48 hours after C-II-a injection. Data are shown as the mean \pm S.E.M 
self-administer the peptide by s.c. injections. Because C-II-a has been shown to improve lipolysis for other forms of hypertriglyceridemia and to promote cholesterol efflux by the ATPbinding cassette transporter A1 (Amar et al., 2015), it may also be useful as a more general therapy for hypertriglyceridemia, such as in metabolic syndrome, obesity, and type II diabetes, and possibly for the prevention of pancreatitis and cardiovascular disease, but this will have to be more thoroughly examined in future animal studies.

In summary, for the first time, we describe the generation of apoC-II mutant mice and characterize their lipid and lipoprotein abnormalities. Based on the results of this hypertriglyceridemic animal model, we demonstrate the feasibility of treating human apoC-II deficiency with C-II-a, an apoC-II mimetic peptide.

\section{Acknowledgments}

The authors thank the Proteomics Core Facility of the National Heart, Lung, and Blood Institute for help on LC-MS/MS. The authors also thank the Electron Microscopy Core Facility of the National Heart, Lung, and Blood Institute for help on electron microscopy.

\section{Authorship Contributions}

Participated in research design: T. Sakurai, Remaley.

Conducted experiments: T. Sakurai, A. Sakurai, Vaisman, Amar,

Liu, Gordon, Drake, Pryor, Sampson, Freeman.

Contributed new reagents or analytic tools: Yang.

Performed data analysis: T. Sakurai, A. Sakurai, Vaisman, Amar,

Liu, Gordon, Drake, Pryor, Sampson, Freeman.

Wrote or contributed to the writing of the manuscript: T. Sakurai, Freeman, Vaisman, Remaley.

\section{References}

Amar MJA, D'Souza W, Turner S, Demosky S, Sviridov D, Stonik J, Luchoomun J, Voogt J, Hellerstein M, and Sviridov D, et al. (2010) 5A apolipoprotein mimetic peptide promotes cholesterol efflux and reduces atherosclerosis in mice. J Pharmacol Exp Ther 334:634-641.

Amar MJA, Sakurai T, Sakurai-Ikuta A, Sviridov D, Freeman L, Ahsan L, and Remaley AT (2015) A novel apolipoprotein C-II mimetic peptide that activates lipoprotein lipase and decreases serum triglycerides in apolipoprotein E-knockout mice. J Pharmacol Exp Ther 352:227-235.

Anantharamaiah GM, Jones JL, Brouillette CG, Schmidt CF, Chung BH, Hughes TA Bhown AS, and Segrest JP (1985) Studies of synthetic peptide analogs of the amphipathic helix. Structure of complexes with dimyristoyl phosphatidylcholine. $J$ Biol Chem 260:10248-10255.

Athyros VG, Giouleme OI, Nikolaidis NL, Vasiliadis TV, Bouloukos VI, Kontopoulos AG, and Eugenidis NP (2002) Long-term follow-up of patients with acute hypertriglyceridemia-induced pancreatitis. J Clin Gastroenterol 34:472-475.

Auclair SM, Bhanu MK, and Kendall DA (2012) Signal peptidase I: cleaving the way to mature proteins. Protein Sci 21:13-25.

Beigneux AP, Davies BSJ, Gin P, Weinstein MM, Farber E, Qiao X, Peale F, Bunting S, Walzem RL, and Wong JS, et al. (2007) Glycosylphosphatidylinositol-anchored high-density lipoprotein-binding protein 1 plays a critical role in the lipolytic processing of chylomicrons. Cell Metab 5:279-291.

Benlian P, Foubert L, Gagné E, Bernard L, De Gennes JL, Langlois S, Robinson W, and Hayden M (1996) Complete paternal isodisomy for chromosome 8 unmasked by lipoprotein lipase deficiency. Am J Hum Genet 59:431-436.

Bloedon LT, Dunbar R, Duffy D, Pinell-Salles P, Norris R, DeGroot BJ, Movva R, Navab M, Fogelman AM, and Rader DJ (2008) Safety, pharmacokinetics, and pharmacodynamics of oral apoA-I mimetic peptide D-4F in high-risk cardiovascular patients. J Lipid Res 49:1344-1352.

Boisfer E, Lambert G, Atger V, Tran NQ, Pastier D, Benetollo C, Trottier JF, Beaucamps I, Antonucci M, and Laplaud M, et al. (1999) Overexpression of human apolipoprotein A-II in mice induces hypertriglyceridemia due to defective very low density lipoprotein hydrolysis. $J$ Biol Chem 274:11564-11572.

Boullart ACI, de Graaf J, and Stalenhoef AF (2012) Serum triglycerides and risk of cardiovascular disease. Biochim Biophys Acta 1821:867-875.

Breckenridge WC, Little JA, Steiner G, Chow A, and Poapst M (1978) Hypertriglyceridemia associated with deficiency of apolipoprotein C-II. $N$ Engl J Med 298:1265-1273.

Brewer HB, Jr (1999) Hypertriglyceridemia: changes in the plasma lipoproteins associated with an increased risk of cardiovascular disease. Am J Cardiol 83 (9B): $3 \mathrm{~F}-12 \mathrm{~F}$.

Brown WV, Levy RI, and Fredrickson DS (1970) Further characterization of apolipoproteins from the human plasma very low density lipoproteins. J Biol Chem $\mathbf{2 4 5}$ 6588-6594.
Carbery ID, Ji D, Harrington A, Brown V, Weinstein EJ, Liaw L, and Cui X (2010) Targeted genome modification in mice using zinc-finger nucleases. Genetics 186: 451-459.

Choo KH and Ranganathan S (2008) Flanking signal and mature peptide residues influence signal peptide cleavage. BMC Bioinformatics 9 (Suppl 12):S15.

Chung BH, Anatharamaiah GM, Brouillette CG, Nishida T, and Segrest JP (1985) Studies of synthetic peptide analogs of the amphipathic helix. Correlation of structure with function. J Biol Chem 260:10256-10262.

Connelly PW, Maguire GF, and Little JA (1987) Apolipoprotein CIISt. Michael. Familial apolipoprotein CII deficiency associated with premature vascular disease. $J$ Clin Invest 80:1597-1606.

Cui X, Ji D, Fisher DA, Wu Y, Briner DM, and Weinstein EJ (2011) Targeted integration in rat and mouse embryos with zinc-finger nucleases. Nat Biotechnol 29: $64-67$.

Dumon MF and Clerc M (1986) Preliminary report on a case of apolipoproteins CI and CII deficiency. Clin Chim Acta 157:239-248.

Eisenberg S, Gavish D, Oschry Y, Fainaru M, and Deckelbaum RJ (1984) Abnormalities in very low, low and high density lipoproteins in hypertriglyceridemia. Reversal toward normal with bezafibrate treatment. J Clin Invest 74:470-482.

Freeman LA (2013) Western blots. Methods Mol Biol 1027:369-385.

Garelnabi M, Lor K, Jin J, Chai F, and Santanam N (2013) The paradox of ApoA5 modulation of triglycerides: evidence from clinical and basic research. Clin Biochem 46:12-19.

Goldberg IJ, Eckel RH, and Abumrad NA (2009) Regulation of fatty acid uptake into tissues: lipoprotein lipase- and CD36-mediated pathways. J Lipid Res $\mathbf{5 0}$ (Suppl): S86-S90.

Gordon SM, Deng J, Lu LJ, and Davidson WS (2010) Proteomic characterization of human plasma high density lipoprotein fractionated by gel filtration chromatography. J Proteome Res 9:5239-5249.

Guilherme A, Virbasius JV, Puri V, and Czech MP (2008) Adipocyte dysfunctions linking obesity to insulin resistance and type 2 diabetes. Nat Rev Mol Cell Biol 9: 367-377.

Harrington JM, Nishanova T, Pena SR, Hess M, Scelsi CL, Widener J, and Hajduk SL (2014) A retained secretory signal peptide mediates high density lipoprotein (HDL) assembly and function of haptoglobin-related protein. J Biol Chem $\mathbf{2 8 9}$ 24811-24820.

Hiller K, Grote A, Scheer M, Münch R, and Jahn D (2004) PrediSi: prediction of signal peptides and their cleavage positions. Nucleic Acids Res 32:W375-379.

Hoffer MJV, van Eck MM, Havekes LM, Hofker MH, and Frants RR (1993) Structure and expression of the mouse apolipoprotein C2 gene. Genomics 17:45-51.

van der Hoogt CC, Berbée JF, Espirito Santo SM, Gerritsen G, Krom YD, van der Zee A, Havekes LM, van Dijk KW, and Rensen PC (2006) Apolipoprotein CI cause hypertriglyceridemia independent of the very-low-density lipoprotein receptor and apolipoprotein CIII in mice. Biochim Biophys Acta 1761:213-220.

Ishihara M, Kujiraoka T, Iwasaki T, Nagano M, Takano M, Ishii J, Tsuji M, Ide H, Miller IP, and Miller NE, et al. (2005) A sandwich enzyme-linked immunosorbent assay for human plasma apolipoprotein A-V concentration. J Lipid Res 46: 2015-2022.

Ito Y, Azrolan N, O’Connell A, Walsh A, and Breslow JL (1990) Hypertriglyceridemia as a result of human apo CIII gene expression in transgenic mice. Science $\mathbf{2 4 9}$ $790-793$

Jarjanazi H, Savas S, Pabalan N, Dennis JW, and Ozcelik H (2008) Biological implications of SNPs in signal peptide domains of human proteins. Proteins $\mathbf{7 0}$ 394-403.

Johansen CT, Kathiresan S, and Hegele RA (2011) Genetic determinants of plasma triglycerides. J Lipid Res 52:189-206.

Kamp F, Guo W, Souto R, Pilch PF, Corkey BE, and Hamilton JA (2003) Rapid flipflop of oleic acid across the plasma membrane of adipocytes. $J$ Biol Chem 278: $7988-7995$

Karpe F, Johansson J, and Carlson LA (1990) Studies on the lecithin: cholesterol acyltransferase substrate properties of HDL as determined by its subclass distribution analysed by gradient gel electrophoresis. Biochim Biophys Acta 1042 310-314.

LaRosa JC, Levy RI, Herbert P, Lux SE, and Fredrickson DS (1970) A specific apoprotein activator for lipoprotein lipase. Biochem Biophys Res Commun 41:57-62.

LeRoith D, Taylor SI, and Olefsky JM (2003) Diabetes mellitus: A fundamental and clinical text, Ed. 3rd, pp 169-170, Lippincott, Philadelphia.

Li P, Ruan X, Yang L, Kiesewetter K, Zhao Y, Luo H, Chen Y, Gucek M, Zhu J, and Cao H (2015) A liver-enriched long non-coding RNA, lncLSTR, regulates systemic lipid metabolism in mice. Cell Metab 21:455-467.

Liu C, Gates KP, Fang L, Amar MJ, Schneider DA, Geng H, Huang W, Kim J, Pattison J, and Zhang J, et al. (2015) Apoc2 loss-of-function zebrafish mutant as a renetic model of hyperlipidemia. Dis Model Mech 8:989-998.

Liu C, Xie W, Gui C, and Du Y (2013) Pronuclear microinjection and oviduct transfer procedures for transgenic mouse production. Methods Mol Biol 1027:217-232.

McIlhargey TL, Yang Y, Wong H, and Hill JS (2003) Identification of a lipoprotein lipase cofactor-binding site by chemical cross-linking and transfer of apolipoprotein C-II-responsive lipolysis from lipoprotein lipase to hepatic lipase. J Biol Chem 278 : 23027-23035

Nesvizhskii AI, Keller A, Kolker E, and Aebersold R (2003) A statistical model for identifying proteins by tandem mass spectrometry. Anal Chem 75:4646-4658

Nordestgaard BG, Benn M, Schnohr P, and Tybjaerg-Hansen A (2007) Nonfasting triglycerides and risk of myocardial infarction, ischemic heart disease, and death in men and women. JAMA 298:299-308.

Nordestgaard BG and Varbo A (2014) Triglycerides and cardiovascular disease. Lancet 384:626-635.

Rashid S, Watanabe T, Sakaue T, and Lewis GF (2003) Mechanisms of HDL lowering in insulin resistant, hypertriglyceridemic states: the combined effect of HDL triglyceride enrichment and elevated hepatic lipase activity. Clin Biochem 36: 421-429. 
Rousset X, Vaisman B, Auerbach B, Krause BR, Homan R, Stonik J, Csako G, Shamburek R, and Remaley AT (2010) Effect of recombinant human lecithin cholesterol acyltransferase infusion on lipoprotein metabolism in mice. J Pharmacol Exp Ther 335:140-148.

Shachter NS, Hayek T, Leff T, Smith JD, Rosenberg DW, Walsh A, Ramakrishnan R, Goldberg IJ, Ginsberg HN, and Breslow JL (1994) Overexpression of apolipoprotein CII causes hypertriglyceridemia in transgenic mice. J Clin Invest 93:1683-1690.

Sharpe CR, Sidoli A, Shelley CS, Lucero MA, Shoulders CC, and Baralle FE (1984) Human apolipoproteins AI, AII, CII and CIII. cDNA sequences and mRNA abundance. Nucleic Acids Res 12:3917-3932.

Sorenson RC, Bisgaier CL, Aviram M, Hsu C, Billecke S, and La Du BN (1999) Human serum Paraoxonase/Arylesterase's retained hydrophobic $\mathrm{N}$-terminal leader sequence associates with HDLs by binding phospholipids : apolipoprotein A-I stabilizes activity. Arterioscler Thromb Vasc Biol 19:2214-2225.

Symoens S, Malfait F, Renard M, André J, Hausser I, Loeys B, Coucke P, and De Paepe A (2009) COL5A1 signal peptide mutations interfere with protein secretion and cause classic Ehlers-Danlos syndrome. Hum Mutat 30:E395-E403.

Thorngate FE, Yancey PG, Kellner-Weibel G, Rudel LL, Rothblat GH, and Williams DL (2003) Testing the role of apoA-I, HDL, and cholesterol efflux in the atheroprotective action of low-level apoE expression. J Lipid Res 44:2331-2338.

Tsuang W, Navaneethan U, Ruiz L, Palascak JB, and Gelrud A (2009) Hypertriglyceridemic pancreatitis: presentation and management. Am J Gastroenterol 104:984-991.

Vedhachalam C, Duong PT, Nickel M, Nguyen D, Dhanasekaran P, Saito H, Rothblat GH, Lund-Katz S, and Phillips MC (2007) Mechanism of ATP-binding cassette transporter A1-mediated cellular lipid efflux to apolipoprotein A-I and formation of high density lipoprotein particles. J Biol Chem 282:25123-25130.
Vu TT, Zhou J, Leslie BA, Stafford AR, Fredenburgh JC, Ni R, Qiao S, Vaezzadeh N, Jahnen-Dechent W, and Monia BP, et al. (2015) Arterial thrombosis is accelerated in mice deficient in histidine-rich glycoprotein. Blood 125:2712-2719.

Wang CS (1991) Structure and functional properties of apolipoprotein C-II. Prog Lipid Res 30:253-258.

Weinstock PH, Bisgaier CL, Aalto-Setälä K, Radner H, Ramakrishnan R, LevakFrank S, Essenburg AD, Zechner R, and Breslow JL (1995) Severe hypertriglyceridemia, reduced high density lipoprotein, and neonatal death in lipoprotein lipase knockout mice. Mild hypertriglyceridemia with impaired very low density lipoprotein clearance in heterozygotes. J Clin Invest 96:2555-2568.

Wilson CJ, Priore Oliva C, Maggi F, Catapano AL, and Calandra S (2003) Apolipoprotein C-II deficiency presenting as a lipid encephalopathy in infancy. Ann Neurol 53:807-810.

van de Woestijne AP, Monajemi H, Kalkhoven E, and Visseren FL (2011) Adipose tissue dysfunction and hypertriglyceridemia: mechanisms and management. Obes Rev 12:829-840.

Xu N and Dahlbäck B (1999) A novel human apolipoprotein (apoM). J Biol Chem 274: 31286-31290.

Zdunek J, Martinez GV, Schleucher J, Lycksell PO, Yin Y, Nilsson S, Shen Y, Olivecrona $\mathrm{G}$, and Wijmenga $\mathrm{S}$ (2003) Global structure and dynamics of human apolipoprotein CII in complex with micelles: evidence for increased mobility of the helix involved in the activation of lipoprotein lipase. Biochemistry 42:1872-1889.

Address correspondence to: Dr. Alan T. Remaley, 10 Center Drive, Building 10/Room 2C433, Bethesda, MD 20892. E-mail: aremaley1@cc.nih.gov 